\title{
Tropospheric aerosol scattering and absorption over central Europe: a closure study for the dry particle state
}

\author{
N. Ma ${ }^{1,2}$, W. Birmili ${ }^{1}$, T. Müller ${ }^{1}$, T. Tuch ${ }^{1}$, Y. F. Cheng ${ }^{3}$, W. Y. Xu ${ }^{2}$, C. S. Zhao ${ }^{2}$, and A. Wiedensohler ${ }^{1}$ \\ ${ }^{1}$ Leibniz Institute for Tropospheric Research, Permoserstr. 15, 04318 Leipzig, Germany \\ ${ }^{2}$ Department of Atmospheric and Oceanic Sciences, School of Physics, Peking University, 100871 Beijing, China \\ ${ }^{3}$ Multiphase Chemistry Department, Max Planck Institute for Chemistry, 55020 Mainz, Germany
}

Correspondence to: N. Ma (ma@tropos.de)

Received: 24 September 2013 - Published in Atmos. Chem. Phys. Discuss.: 28 October 2013

Revised: 17 April 2014 - Accepted: 17 April 2014 - Published: 24 June 2014

\begin{abstract}
This work analyses optical properties of the dry tropospheric aerosol measured at the regional Global Atmosphere Watch (GAW) observation site Melpitz in East Germany. For a continuous observation period between 2007 and 2010, we provide representative values of the dry-state scattering coefficient, hemispheric backscattering coefficient, absorption coefficient, single scattering albedo, and scattering Ångström exponent. Besides the direct measurement, the aerosol scattering coefficient was alternatively computed from experimental particle number size distributions using a Mie model. Within pre-defined limits, a closure could be achieved with the direct measurement. The achievement of closure implies that such calculations can be used as a highlevel quality control measure for data sets involving multiple instrumentation.

All dry-state optical properties show pronounced annual and diurnal variations, which are attributed to the corresponding variations in the regional emission fluxes, the intensity of secondary particle formation, and the mixing layer height. Air mass classification shows that atmospheric stability is a major factor influencing the dry aerosol properties at the GAW station. In the cold season, temperature inversions limit the volume available for atmospheric mixing, so that the dry-state aerosol optical properties near the ground proved quite sensitive to the geographical origin of the air mass. In the warm season, when the atmosphere is usually well-mixed during daytime, considerably less variability was observed for the optical properties between different air masses. This work provides, on the basis of quality-checked in situ measurements, a first step towards a climatological assessment of direct aerosol radiative forcing in the region under study.
\end{abstract}

\section{Introduction}

Atmospheric aerosols influence the Earth's radiation budget in several ways: first, by directly scattering and absorbing solar radiation (Charlson et al., 1992), and second, by acting as cloud condensation nuclei and thus affecting the optical properties and lifetimes of clouds (Twomey, 1974; Albrecht, 1989; Rosenfeld, 1999, 2000). The effective radiative forcing caused by these two effects is estimated as -0.45 and $-0.45 \mathrm{Wm}^{-2}$, respectively, with their uncertainties being the largest among all climate forcing factors (IPCC, 2013). Very differently from the well-mixed greenhouse gases such as $\mathrm{CO}_{2}$ and methane, aerosols show considerable spatial and temporal inhomogeneities in the atmosphere (van Donkelaar et al., 2010; Liu et al., 2009). This makes an assessment of aerosol-related climate effects substantially more complicated than those related to greenhouse gases.

Satellites monitor aerosol optical properties on a global scale. However, the determination of aerosol-related radiative forcing on the basis of satellites measurements requires assumptions for certain microphysical aerosol optical parameters that cannot be measured by satellites (Tanré et al., 1997). Variations in these aerosol parameters, as they naturally occur in the atmosphere, can propagate into considerable uncertainties in the satellite-retrieved aerosol properties. In situ studies of the spatial and temporal variation of aerosol optical properties are therefore a vital step in reducing the uncertainty of radiative forcing effects derived from passive remote sensing data (Delene et al., 2002).

Also, aerosol optical properties and their uncertainties are very important for the scientific modelling community. 
Long-term measurement of aerosol optical properties can be used to develop the parameterizations for important properties and further used in transport models, reducing the uncertainties induced by the insufficiency of information on aerosol properties.

There have been a number of studies reporting long-term (i.e. longer than one year) in situ measurements of aerosol optical properties (see e.g. Collaud Coen et al., 2013, and references listed in Table 8). However, none of these works describes aerosol optical properties for the background troposphere in central Europe. To close this gap, we analysed a body of dry-state aerosol number size distribution, aerosol scattering and absorption coefficient at the research station Melpitz in East Germany between 2007 and 2010. This paper discusses the measured values on a statistical basis, and analyses temporal variations of the parameters. Aerosol scattering and absorption coefficients are calculated from experimental particle number size distribution, striving for a closure with the directly measured value. A classification of the aerosol optical properties according to different air mass types rounds up the analysis.

\section{Methodology}

\subsection{Experimental}

Aerosol number size distributions and aerosol scattering and absorption coefficients were measured at the research station Melpitz in East Germany (51 $32^{\prime} \mathrm{N}, 12^{\circ} 56^{\prime} \mathrm{E}$; $86 \mathrm{~m}$ a.s.1.). While these measurements were operated on a continuous basis, this study employs a complete continuous data set spanning the years 2007-2010.

The surroundings of the Melpitz station are flat grassland, agricultural pastures, and wooded areas. The nearest major city Leipzig (pop. 500 000) is $44 \mathrm{~km}$ to the southwest. Melpitz is $400 \mathrm{~km}$ from the North Sea, and about $1000 \mathrm{~km}$ from the Atlantic coast. Melpitz station is part of the measurement networks EMEP, ACTRIS (Aerosols, Clouds, and Trace gases Research InfraStructure Network), GUAN (German Ultrafine Aerosol Network; Birmili et al., 2009), and a regional station in WMO-GAW (Global Atmosphere Watch). For an overview of the physical and chemical aerosol measurements at Melpitz, see Birmili et al. (2008). According to a comparison with particle size distribution measurements collected elsewhere in Europe (Asmi et al., 2011), aerosol data collected at Melpitz is representative of the troposphere over central Europe.

All aerosol instrumentation was operated inside a container laboratory. Ambient aerosol was aspired through a common $\mathrm{PM}_{10}$ Andersen inlet, and later divided among different instruments inside the container. A regenerative absorption dryer (Tuch et al., 2009) was installed on the roof of the container to reduce the dew point in the sample aerosol.
Operation of the dryer ensured relative humidity below $40 \%$ in all instruments at any time.

The aerosol scattering and hemispheric backscattering coefficients $\left(\sigma_{\mathrm{sp}}\right.$ and $\left.\sigma_{\mathrm{bsp}}\right)$ for dry aerosol were measured by a total/back integrating nephelometer (Model 3563, TSI, Inc., Shoreview, MN USA; Heintzenberg and Charlson, 1996; Anderson et al., 1996) at wavelengths of 450, 550 and $700 \mathrm{~nm}$. Checks with particle-free zero air were performed four times per day. The truncation and non-Lambertian errors were corrected for the whole data set using the most up-to-date method (Sect. 3.2).

The aerosol absorption coefficient $\left(\sigma_{\text {ap }}\right)$ for dry aerosols was measured with a Multi-angle Absorption Photometer (MAAP Model 5012, Thermo, Inc., Waltham, MA USA; Petzold and Schönlinner, 2004) at a wavelength of $637 \mathrm{~nm}$ (Müller et al., 2011). The instrument provides mass concentrations of black carbon (BC) in $\mu \mathrm{g} \mathrm{m}^{-3}$. Following the user manual, the originally measured $\sigma_{\text {ap }}$ was retrieved by multiplying mass concentration by the mass absorption coefficient of $6.6 \mathrm{~m}^{2} \mathrm{~g}^{-1}$.

A Twin Differential Mobility Particle Sizer (TDMPS; Birmili et al., 1999) measured dry aerosol number size distributions for the mobility diameter range $3-800 \mathrm{~nm}$. The measurements were performed in compliance with recently issued guidelines for atmospheric particle size distribution measurements (Wiedensohler et al., 2012). Briefly, the evaluation of particle number size distributions involved a multiple charge correction (Pfeifer et al., 2014), corrections for the counting efficiency of the condensation particle counters (Wiedensohler et al., 1997), and corrections for the transmission losses in the differential mobility analysers, and all the internal and external plumbing of the instrument.

An Aerodynamic Particle Sizer (APS Model 3320, TSI, Inc., Shoreview, MN USA) was employed to measure dry aerosol number size distributions for aerodynamic diameter between 0.5 and $10 \mu \mathrm{m}$. Electrical mobility diameters from the TDMPS and aerodynamic diameters from the APS were converted to volume equivalent diameters according to DeCarlo et al. (2004), assuming size-dependent gravimetric densities and shape factors. According to McMurry et al. (2002), the fine-mode particles were assumed as spherical (shape factor $=1$ ), with a density of $1.6 \mathrm{~g} \mathrm{~cm}^{-3}$. The coarsemode particles were assumed to be mainly mineral dust. According to Kaaden et al. (2009), the shape factor and density were assumed to be 1.26 and $2.5 \mathrm{~g} \mathrm{~cm}^{-3}$, respectively. After these adjustments, the TDMPS and APS distributions were merged to a continuous distribution ranging from $3 \mathrm{~nm}$ to $10 \mu \mathrm{m}$.

\subsection{Optical closure for dry aerosol}

Closure studies are useful to estimate the uncertainties of measurement techniques on the one hand, and numerical models on the other hand (Quinn et al., 1996). Many studies have employed aerosol optical closure as a quality 
examination of their measurements (e.g. Wex et al., 2002; Ma et al., 2011; Zieger et al., 2014). Here, we performed a closure study for the dry-state aerosol optical properties as part of an examination of the quality of our aerosol measurements. Concretely, the $\sigma_{\mathrm{sp}}$ and $\sigma_{\mathrm{bsp}}$ measured by TSI 3563 nephelometer were compared with the values computed from the particle number size distribution measurements using a modified Mie model.

To simulate the measurements of TSI 3563 nephelometer, a modified BHMIE model and a modified BHCOAT model (Bohren and Huffman, 1983; Cheng et al., 2009; Ma et al., 2011) were used for homogeneous spherical particles and core-shell mixed spherical particles, respectively.

In the Mie theory (Mie, 1908), the scattering efficiency $\left(Q_{\mathrm{sp}}\right)$ and hemispheric backscattering efficiency $\left(Q_{\mathrm{bsp}}\right)$ can be calculated by integrating the scattering intensity function $|S(\theta, x, \tilde{m})|$ from 0 to $180^{\circ}$ and from 90 to $180^{\circ}$, respectively:

$$
Q_{\text {sp,bsp }}=\frac{1}{x^{2}} \int_{\theta}|S(\theta, x, \tilde{m})|^{2} \sin \theta \mathrm{d} \theta,
$$

where $x=\pi D_{\mathrm{p}} / \lambda$, where $D_{\mathrm{p}}$ is the volume equivalent diameter of particles, $\lambda$ is the wavelength of light, and $\theta$ is the scattering angle.

Different from the regular scattering angle ranges mentioned above, the scattering integration angle of TSI 3563 nephelometer ranges from 7 to $170^{\circ}$ for scattering and from 90 to $170^{\circ}$ for hemispheric backscattering, respectively. Thus, the measurements are truncated in the near-forward and near-backward angular ranges. Furthermore, the light source of nephelometer is not strictly Lambertian and shows a non-ideal angular response (Anderson et al., 1996). The angular response is solved in the Mie calculations based on the BHMIE and BHCOAT model (Bohren and Huffman, 1983). The $\sin \theta$ term in Eq. (1) is replaced by the angular sensitivity curves $f(\theta)_{\text {sp }}$ and $f(\theta)_{\text {bsp }}$ which are derived from a calibration experiment of the TSI 3563 nephelometer (Anderson et al., 1996). The $\sigma_{\mathrm{sp}}$ and $\sigma_{\mathrm{bsp}}$ are calculated as

$$
\begin{aligned}
\sigma_{\mathrm{sp}, \mathrm{bsp}} & =\int_{D_{\mathrm{p}}}\left[\frac{1}{x^{2}} \int_{\theta}|S(\theta, x, \tilde{m})|^{2} f(\theta)_{\mathrm{sp}, \mathrm{bsp}} \mathrm{d} \theta\right] \\
& \cdot\left(\frac{\pi}{4} D_{\mathrm{p}}^{2}\right) \cdot n\left(\log D_{\mathrm{p}}\right) \cdot \mathrm{d} \log D_{\mathrm{p}},
\end{aligned}
$$

where $n\left(\log D_{\mathrm{p}}\right)$ is the aerosol number size distribution.

In the calculation of dry-state $\sigma_{\mathrm{sp}}$ and $\sigma_{\mathrm{bsp}}$, the particulate species are divided into two fundamental groups. These include, on the one hand, light-absorbing carbon and, on the other hand, the less absorbing components including sulfate, nitrate, ammonium, organic matter, and other undetermined compounds (see Wex et al., 2002). Although the chemical composition within the latter group is rather different, the refractive indices of these less absorbing species are basi- cally very similar, implying similar optical properties. Representative refractive indices for these two groups were extracted from a range of literature sources (Ouimette and Flagan, 1982; Hasan and Dzubay, 1983; Sloane, 1984; Seinfeld and Pandis, 1998; Covert et al., 1990; Tang and Munkelwitz, 1994), yielding $\tilde{m}_{\mathrm{LAC}}=1.75-0.55 \mathrm{i}$ for light-absorbing carbon and $\tilde{m}_{\text {less }- \text { abs }}=1.53-10^{-6} \mathrm{i}$ for the less absorbing components.

Three kinds of conceptual models are usually applied to describe the mixing state of light-absorbing carbon and less absorbing components: (1) external mixture, (2) homogeneous internal mixture and (3) core-shell internal mixture. In the external mixture, different compounds are separated as different particles; while in the internal mixture, all particles consist of the same mixture of compounds (Winkler, 1973). These conceptual models have been widely used to assess aerosol optical properties and direct radiative forcing. Among the internal mixture models, the core-shell mixture model - suggesting that light-absorbing carbon cores are surrounded by shells of less absorbing components, has been shown to yield more realistic results than the homogeneous internal mixture model (Jacobson, 2001; Chandra et al., 2004; Katrinak et al., 1992, 1993; Ma et al., 2012). Since atmospheric aerosols are likely to be a partial mixture of externally and internally mixed particles, external mixture and core-shell internal mixture were considered as the limit cases of the aerosol mixing state in this study. Homogeneous internal mixture was also used in the calculations as a reference case.

Lacking information on size-resolved volume/mass concentration of light-absorbing carbon, its volume fraction is assumed to be size independent. The volume fraction of light-absorbing carbon $\left(f_{\mathrm{LAC}}\right)$ can be calculated as

$$
f_{\mathrm{LAC}}=\frac{m_{\mathrm{LAC}, \mathrm{MAAP}}}{\rho_{\mathrm{LAC}} \cdot \sum_{D_{\mathrm{p}}}\left[\frac{\pi}{6} D_{\mathrm{p}}^{3} \cdot n\left(\log D_{\mathrm{p}}\right) \cdot \Delta \log D_{\mathrm{p}}\right]},
$$

where $m_{\text {LAC,MAAP }}$ is the mass concentration of lightabsorbing carbon measured by MAAP, $\rho_{\mathrm{LAC}}$ is the density of light-absorbing carbon, and $n\left(\log D_{\mathrm{p}}\right)$ is the aerosol number size distribution measured by TDMPS and APS. In the literature (Sloane et al., 1983, 1984, 1991; Sloane and Wolff, 1985; Ouimette and Flagan, 1982; Seinfeld and Pandis, 1998), the gravimetric density of light-absorbing carbon is reported to range from 1.00 to $2.00 \mathrm{~g} \mathrm{~cm}^{-3}$. An average value of $1.5 \mathrm{~g} \mathrm{~cm}^{-3}$ was chosen, with an estimated uncertainty of $33 \%$ to cover a range of possible values.

For the case of external mixture, the number size distribution of light-absorbing carbon particles and less absorbing component particles can be derived with $n_{\text {LAC }}\left(D_{\mathrm{p}}\right)=$ $n\left(D_{\mathrm{p}}\right) \cdot f_{\mathrm{LAC}}$ and $n_{\text {less }- \text { abs }}\left(D_{\mathrm{p}}\right)=n\left(D_{\mathrm{p}}\right) \cdot\left(1-f_{\mathrm{LAC}}\right)$, respectively. For the case of core-shell internal mixture, the diameter of the light-absorbing carbon core $\left(D_{\text {core }}\right)$ of a particle with a diameter of $D_{\mathrm{p}}$ can be calculated as: $D_{\text {core }}=D_{\mathrm{p}} f_{\mathrm{LAC}}^{\frac{1}{3}}$. 
For the case of homogeneously internal mixture, the refractive index of mixed particles can be derived as a volumeweighted average between the refractive indices of the two groups:

$\tilde{m}=\tilde{m}_{\mathrm{LAC}} \cdot f_{\mathrm{LAC}}+\tilde{m}_{\text {less }-\mathrm{abs}} \cdot\left(1-f_{\mathrm{LAC}}\right)$.

\subsection{Air mass classification}

To attribute the measured optical aerosol properties to specific air mass types, we divided the experimental data set according to several air mass classification schemes. The first scheme is a recently developed air mass classification scheme for surface-level tropospheric aerosols, and involves a clustering of numerical back trajectories and measured profiles of pseudo-potential temperature (denoted back-trajectory cluster method, BCLM, hereafter). The usefulness of this classification has been demonstrated in several previous works (Engler et al., 2007; Birmili et al., 2010; Heintzenberg et al., 2011). The second and third schemes are established classification schemes that have taken part in comparisons of the Cost 733 action (Philipp et al., 2010): the Hess and Brezowsky Grosswetterlagen scheme (Cost No. 1, "HBGWL", Hess and Brezowsky, 1952), and Objective Weather Classification (Cost No. 19, "WLKC09", Dittmann et al., 1995). These two schemes are described in more detail in the Supplement. With respect to the segregation of aerosol optical measurements at Melpitz, the latter two classification schemes turned out to be less useful than the BCLM method. Nevertheless, their corresponding results are shown in the Supplement.

The BCLM is based on a joint cluster analysis of daily back trajectories and profiles of pseudo-potential temperature obtained from radiosoundings (Engler et al., 2007; Birmili et al., 2010). Pseudo-potential temperature is included in the method because it is an essential indicator on whether the boundary layer can be considered mixed or not during daytime. Technically, the cluster algorithm belongs to the family of $k$-means cluster algorithms. Our modified method, used for the first time here, uses extended functionality in that it processes simultaneously back trajectories started at nine locations spread over Germany, and on radiosoundings measured at seven locations. The cluster algorithm thus yields air mass types that are representative for entire Germany. 3-D backward trajectories were calculated using a PC version of HYSPLIT, a trajectory model provided by the NOAA Air Resources Laboratory (Draxler and Hess, 2004). Back trajectories were calculated from the Global Data Assimilation System (GDAS) analysis set, which provides meteorological fields every $3 \mathrm{~h}$, a spatial horizontal resolution of $1^{\circ}$, and a vertical resolution corresponding to the standard pressure levels $(1000,925,850 \mathrm{hPa}$, etc.). Backward trajectories starting at 12:00 UTC and reaching $96 \mathrm{~h}$ back in time were computed for a starting level of $500 \mathrm{~m}$ above the ground. Radio soundings were started daily at 12:00 UTC at seven meteorological stations in Germany. 12:00 UTC corre-

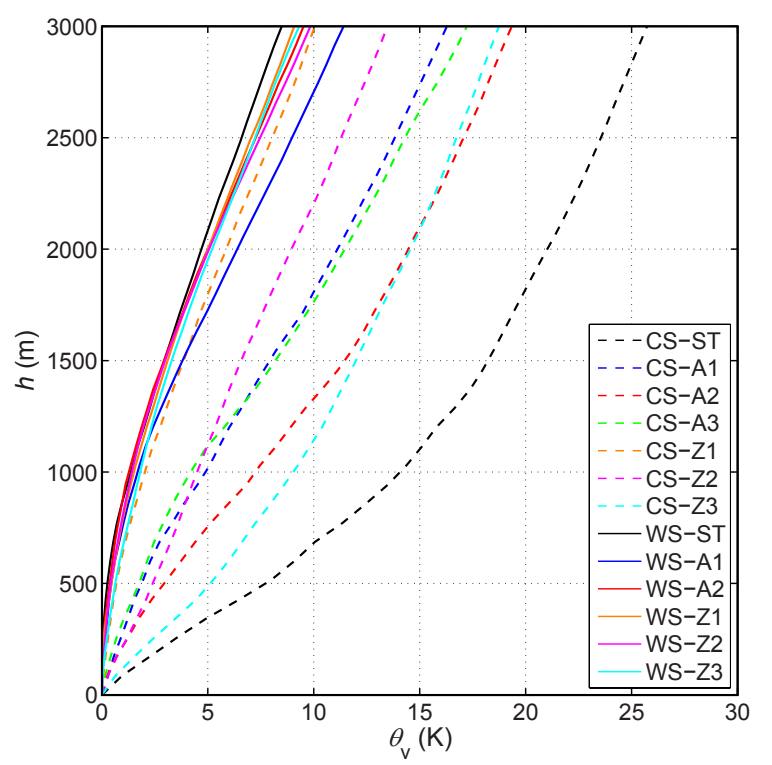

Figure 1. Average normalized profiles of pseudo-potential temperature $\left(\theta_{v}\right)$ for the 13 air mass types reported. Profiles with a flat gradient indicate a temperature inversion. Profiles with a steep gradient imply stratification close to neutral. Data originate from the radiosoundings launched at the DWD station Lindenberg, located $115 \mathrm{~km}$ northeast of Melpitz.

sponds to $13: 00 \mathrm{LT}$, i.e. a time close to the daily maximum of the mixing layer height, which is typically reached around 15:00 LT in the convective boundary layer (Beyrich, 1995). The radio sounding will therefore indicate with high probability whether the atmosphere was well mixed on a particular day or not. To distinguish between different degrees of atmospheric stability, we extracted the pseudo-potential temperature $\left(\theta_{v}\right)$. Under the neutrally stable conditions which are typical for a convective boundary layer, $\theta_{v}$ will show no pronounced gradient with height (see, for example, the "WS"-type air masses in Fig. 1). Conversely, stable atmospheric conditions are evidenced by an increase in $\theta_{v}$ with height. Such temperature inversions may exhibit gradients in pseudo-potential temperature up to $1.6 \mathrm{~K}$ per $100 \mathrm{~m}$ (Fig. 1), so that vertical mixing of air near the ground will be practically inhibited. To make the vertical profiles comparable throughout all seasons, all profiles were normalized to $0{ }^{\circ} \mathrm{C}$ at a height of $100 \mathrm{~m}$ above ground.

The principal aim of the cluster method is to produce air mass types that diverge as much as possible in terms of back trajectories and vertical stratification. An additional goal was to achieve a classification scheme with a high predictive power for particulate matter mass concentrations near the surface. Around 1000 runs of the algorithm were performed that varied in terms of seed trajectories and relative weights of the contributions of trajectories and radiosounding profiles to the total distance measure. These runs were evaluated 


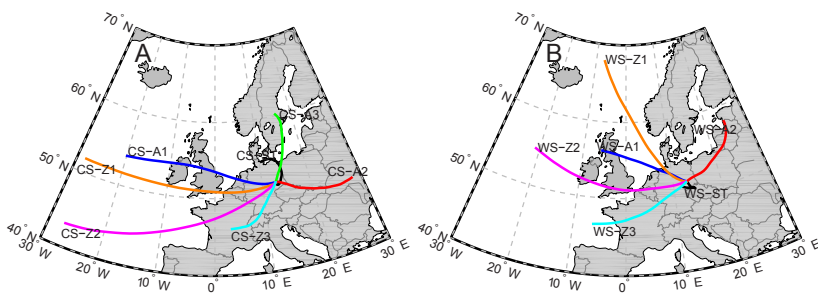

Figure 2. Average back trajectories, terminating at Melpitz, for the 13 air mass types investigated. (A) and (B) display the air mass types associated with more stable stratification (CS, cold season) and less stable stratification (WS, warm season), respectively. The duration of the back trajectories is $72 \mathrm{~h}$.

regarding their ability to efficiently divide the data set into subsets of high and low $\mathrm{PM}_{10}$ surface concentrations.

The resulting 13 clusters are described in Table 1, and the mean back trajectories are illustrated in Fig. 2. It can be seen that the clusters break down into several categories: type of stratification (referring to 12:00 UTC), type of atmospheric flow (cyclonic/anticyclonic), and region of origin. The type of stratification changes, of course, throughout the year. Figure 1 shows the average profiles of pseudo-potential temperature $\left(\theta_{v}\right)$ for the 13 air mass types reported. To describe the resulting clusters more plastically, the clusters referring to stable stratification were named after the "cold season, CS". Conversely, clusters referring to rather neutrally stable stratification were named after the "warm season, WS". As a reference, the average $\mathrm{PM}_{10}$ mass concentrations at 53 rural background sites in Germany is also shown in Table $1 . \mathrm{PM}_{10}$ mass concentrations in Germany are recorded on a continuous basis by federal and regional government air quality monitoring networks Graphical and tabular versions can be accessed on Germany's Federal Environment Agency UBA website (http://www.umweltbundesamt.de/). At each individual regional environment agency $\mathrm{PM}_{10}$ might be measured by a different method, including the gravimetric reference method, TEOMs, beta-gauges, and optical particle counters. Final versions of the data, however, are always corrected to the levels of the gravimetric reference method (CEN, 1998) involving $24 \mathrm{~h}$ filter sampling.

\section{Results and discussion}

\subsection{Optical closure}

We first report on the closure for the dry-state aerosol optical scattering coefficients $\left(\sigma_{\mathrm{sp}}\right.$ and $\left.\sigma_{\mathrm{bsp}}\right)$, because this illustrates the quality of the given data set. As described in Sect. 2.2, $\sigma_{\mathrm{sp}}$ and $\sigma_{\text {bsp }}$ were calculated from the measured particle number size distributions and the light-absorbing carbon concentrations using a modified Mie model. The calculations were carried out under the assumptions of external mixture, coreshell internal mixture and homogeneous internal mixture for the mixing state of light-absorbing carbon and less absorbing components for the wavelengths of 450,550 and $700 \mathrm{~nm}$ corresponding to those measured by the nephelometer. Calculations were applied to a total of 65282 data records measured from 2008 to 2010 (each data record covers a $10 \mathrm{~min}$ measurement interval). Data from 2007 was omitted due to the incompleteness of APS number size distributions. The optical closure was conducted before the correction of the truncation and non-Lambertian error of nephelometer measurement.

\subsubsection{Comparison between calculated and measured parameters}

Results show that measured and calculated $\sigma_{\mathrm{sp}}$ and $\sigma_{\mathrm{bsp}}$ are highly correlated. Also, the values calculated on the basis of different mixing state assumptions are quite close. Linear fits were performed to quantify the relationship between measured and calculated $\sigma_{\mathrm{sp}}$ and $\sigma_{\text {bsp. }}$. The relationship between measured and calculated values was assumed to be $\sigma_{\text {calculated }}=b \sigma_{\text {measured }}$. Since the data points recorded at the Melpitz site spread over three orders of magnitudes, if the fitting was applied in linear coordinates, points with large values would be over-represented. Therefore, fitting was performed with log-scaled values using the modified formula $\log \left(\sigma_{\text {calculated }}\right)=\log (b)+\log \left(\sigma_{\text {measured }}\right)$. Table 2 summarizes the fitting parameters $(b)$ and the determination coefficients $\left(R^{2}\right)$ of $\sigma_{\mathrm{sp}}$ and $\sigma_{\mathrm{bsp}}$ for all the three wavelengths. It can be noted that all the $R^{2}$ of $\sigma_{\mathrm{sp}}$ are higher than 0.98 (except for $\sigma_{\mathrm{sp}}$ at $700 \mathrm{~nm}$ based on core-shell internal mixture), indicating significant linear relationship between measured and calculated values. The $R^{2}$ of $\sigma_{\text {bsp }}$ are slightly lower than those of $\sigma_{\mathrm{sp}}$ but still higher than 0.97. Almost all the fitting parameters $b$ are below 1, indicating some underestimation by all model variants.

On average, the calculated $\sigma_{\mathrm{sp}}$ based on the external mixture assumption are 9.5 and $10.8 \%$ higher than those based on the assumption of a homogeneous internal mixture and the core-shell internal mixture, respectively. The calculated $\sigma_{\text {bsp }}$ based on the external mixture assumption are $16.6 \%$ higher and $4.6 \%$ lower than those based on the assumption of a homogeneous internal mixture and the core-shell internal mixture, respectively. The variations in calculated $\sigma_{\mathrm{bsp}}$ are larger than those in $\sigma_{\mathrm{sp}}$ because $\sigma_{\mathrm{bsp}}$ reacts more sensitively to the changes in the mixing state of light-absorbing carbon than $\sigma_{\text {sp }}$ (Ma et al., 2012).

\subsubsection{Uncertainty analysis approach}

It is reasonable to understand that the calculated and measured $\sigma_{\mathrm{sp}}$ and $\sigma_{\mathrm{bsp}}$ do not match exactly. Finite uncertainties are attached to the experimental data, as well as the assumed model input parameters. Next, certain assumptions underlying the model calculations might not be true and are expected to bias the calculated parameters. Therefore, the uncertainties of the input data, the assumptions underlying the models, and 
Table 1. Characteristics of the 13 air mass types determined for central Europe based on trajectory and temperature profile clustering.

\begin{tabular}{|c|c|c|c|c|c|c|c|}
\hline $\begin{array}{l}\text { Air } \\
\text { mass } \\
\text { type }\end{array}$ & $\begin{array}{l}\text { Vertical } \\
\text { stratification } \\
\text { at 12:00 UTC }\end{array}$ & $\begin{array}{l}\text { Predominant } \\
\text { period } \\
\text { of the year }\end{array}$ & $\begin{array}{l}\text { Atmospheric } \\
\text { flow }\end{array}$ & $\begin{array}{l}\text { Source } \\
\text { region }\end{array}$ & $\begin{array}{l}\text { Predominant wind } \\
\text { direction at Melpitz }\end{array}$ & $\begin{array}{r}\text { Climatological } \\
\text { frequency } \\
2005-2011\end{array}$ & $\begin{array}{l}\text { Mean } \mathrm{PM}_{10} \text { at } 53 \\
\text { rural background } \\
\text { sites in Germany }\end{array}$ \\
\hline CS-ST & very stable & cold season & stagnant & Central Europe & - & $2.7 \%$ & $34 \mu \mathrm{g} \mathrm{m}^{-3}$ \\
\hline CS-A1 & stable & cold season & anticyclonic & North Atlantic & west & $5.8 \%$ & $16 \mu \mathrm{g} \mathrm{m}^{-3}$ \\
\hline CS-A2 & stable & cold season & anticyclonic & Eastern Europe & east & $4.1 \%$ & $32 \mu \mathrm{g} \mathrm{m}^{-3}$ \\
\hline CS-A3 & stable & cold season & anticyclonic & Northern Europe & north & $6.1 \%$ & $18 \mu \mathrm{g} \mathrm{m}^{-3}$ \\
\hline CS-Z1 & close to neutral & cold season & cyclonic & North Atlantic & west & $4.6 \%$ & $12 \mu \mathrm{g} \mathrm{m}^{-3}$ \\
\hline $\mathrm{CS}-\mathrm{Z2}$ & stable & cold season & cyclonic & North Atlantic & west/south-west & $5.6 \%$ & $12 \mu \mathrm{g} \mathrm{m}^{-3}$ \\
\hline CS-Z3 & stable & cold season & cyclonic & South west Europe & south-west & $5.7 \%$ & $23 \mu \mathrm{g} \mathrm{m}^{-3}$ \\
\hline WS-ST & close to neutral & warm season & stagnant & Central Europe & - & $10.7 \%$ & $22 \mu \mathrm{g} \mathrm{m}^{-3}$ \\
\hline WS-A1 & close to neutral & warm season & anticyclonic & North Atlantic & north-west & $11.6 \%$ & $17 \mu \mathrm{g} \mathrm{m}^{-3}$ \\
\hline WS-A2 & close to neutral & warm season & anticyclonic & Eastern Europe & north-east/east & $9.6 \%$ & $20 \mu \mathrm{g} \mathrm{m}^{-3}$ \\
\hline WS-Z1 & close to neutral & warm season & cyclonic & North Atlantic & north-west & $11.2 \%$ & $12 \mu \mathrm{g} \mathrm{m}^{-3}$ \\
\hline WS-Z2 & close to neutral & warm season & cyclonic & North Atlantic & west & $12.5 \%$ & $13 \mu \mathrm{g} \mathrm{m}^{-3}$ \\
\hline WS-Z3 & close to neutral & warm season & cyclonic & South west Europe & south-west & $10.0 \%$ & $16 \mu \mathrm{g} \mathrm{m}^{-3}$ \\
\hline
\end{tabular}

Table 2. The fit parameters ( $b$ and $R^{2}$ ) of the linear fits for calculated and measured $\sigma_{\mathrm{sp}}$ and $\sigma_{\mathrm{bsp}}$ with $\log \left(\sigma_{\text {calculated }}\right)=\log (b)+$ $\log \left(\sigma_{\text {measured }}\right)$.

\begin{tabular}{rrrrrrrr}
\hline & & \multicolumn{2}{c}{ Internal } & \multicolumn{2}{c}{ Core-shell } & \multicolumn{2}{c}{ External } \\
\hline \multirow{4}{*}{$\sigma_{\text {sp }}$} & $\lambda(\mathrm{nm})$ & $b$ & $R^{2}$ & $b$ & $R^{2}$ & $b$ & $R^{2}$ \\
\hline \multirow{6}{*}{$\sigma_{\text {bsp }}$} & 450 & 0.8809 & 0.9827 & 0.8689 & 0.9815 & 0.9732 & 0.9854 \\
& 550 & 0.9196 & 0.9831 & 0.9093 & 0.9820 & 1.0061 & 0.9854 \\
& 700 & 0.9344 & 0.9801 & 0.9298 & 0.9795 & 1.0140 & 0.9825 \\
\hline & 450 & 0.7419 & 0.9706 & 0.9458 & 0.9799 & 0.8883 & 0.9817 \\
& 550 & 0.7911 & 0.9731 & 0.9655 & 0.9811 & 0.9210 & 0.9819 \\
& 700 & 0.7518 & 0.9745 & 0.8727 & 0.9838 & 0.8432 & 0.9824 \\
\hline
\end{tabular}

their propagation into the output values should be evaluated. If the measured values then fall within such a defined range, the closure can be considered to be "achieved".

To evaluate the uncertainties of the calculated $\sigma_{\mathrm{sp}}$ and $\sigma_{\text {bsp }}$ induced by the uncertainties of the input parameters of the Mie model, a Monte Carlo simulation was used in this study. The input parameters of the Mie model include in situ measured data (particle number size distributions and light-absorbing carbon mass concentrations) and some constants assumed beforehand (the refractive indices of light-absorbing carbon and less absorbing components, and the density of light-absorbing carbon). The uncertainties of the measured particle number size distributions and light-absorbing carbon mass concentrations ( $m_{\text {LAC,MAAP }}$ ) were set according to Wiedensohler et al. (2012), Wex et al. (2002) and Petzold and Schönlinner (2004), as shown in Table 3. It should be noted that organic carbon may also include light-absorbing components, such as HUmic-LIke Substances (HULIS, Graber and Rudich, 2006). However, a constant mass absorption efficiency $\left(6.6 \mathrm{~m}^{2} \mathrm{~g}^{-1}\right)$ was used by MAAP, probably causing a bias in the reported BC mass concentrations. As mentioned in Sect. 2.2, the uncertainty
$(3 \sigma)$ of the density of light-absorbing carbon was set to $33 \%$ to cover the possible range reported in the literature. The uncertainties for the refractive indices were also chosen to agree with the values reported in the literature (Ouimette and Flagan, 1982; Hasan and Dzubay, 1983; Sloane, 1984; Seinfeld and Pandis, 1998; Covert et al., 1990; Tang and Munkelwitz, 1994), as shown in Table 3. According to Heintzenberg et al. (2006), the uncertainty of measured $\sigma_{\mathrm{sp}}$ and $\sigma_{\mathrm{bsp}}$ is estimated as $10 \%$.

Mie calculations were repeated using an independently randomly varied set of input parameters. The random values were created forming normal distributions with standard deviations chosen according to Table 3. From the 65282 records of the whole data set, 2000 records were selected randomly for the Monte Carlo simulation. Several hundreds of runs were done for each of the 2000 records to obtain the standard deviations of the calculated $\sigma_{\mathrm{sp}}$ and $\sigma_{\mathrm{bsp}}$ at the three wavelengths of nephelometer, and under the three assumed mixing states. And the average standard deviations of the 2000 records were considered as the standard deviations of the model results. As listed in Table 4, for different wavelengths and mixing state assumptions, the average relative standard deviations for calculated $\sigma_{\mathrm{sp}}$ range from 7.99 to $8.70 \%$, while those for $\sigma_{\text {bsp }}$ range from 6.85 to $8.02 \%$.

\subsubsection{Uncertainty analysis results}

Comparisons between measured and calculated $\sigma_{\mathrm{sp}}$ and $\sigma_{\mathrm{bsp}}$ were carried out taking into account the uncertainties of the measurements and the calculations. For $\sigma_{\mathrm{sp}}$ and $\sigma_{\mathrm{bsp}}$, the calculated values with external mixture assumption plus triple standard deviation and the calculated values with core-shell internal mixture assumption minus triple standard deviation were considered as the boundaries of the possible range within which the measured values should fall. The fractions of the data records that satisfy this closure criterion were 
Table 3. Uncertainties of the input parameters of the Mie model, given as one standard deviation.

\begin{tabular}{|c|c|c|}
\hline Parameter & Description of parameter & $\begin{array}{r}\text { Standard } \\
\text { deviation } \\
(\sigma, \%)\end{array}$ \\
\hline$D_{\mathrm{p}, \mathrm{TDMPS}}$ & Particle diameter measured by TDMPS & 1.1 \\
\hline$D_{\mathrm{p}, \mathrm{APS}}$ & Particle diameter measured by APS & 3 \\
\hline$N_{\text {TDMPS }, 3-20 \mathrm{~nm}}$ & Aerosol number concentration measured by TDMPS for bins between 3 and $20 \mathrm{~nm}$ & 10 \\
\hline$N_{\text {TDMPS }, 20-200 \mathrm{~nm}}$ & Aerosol number concentration measured by TDMPS for bins between 20 and $200 \mathrm{~nm}$ & 3.3 \\
\hline$N_{\text {TDMPS }, 200-700 \mathrm{~nm}}$ & Aerosol number concentration measured by TDMPS for bins between 200 and $700 \mathrm{~nm}$ & 8.3 \\
\hline$N_{\text {APS }}$ & Aerosol number concentration measured by APS & 3.3 \\
\hline$m_{\mathrm{LAC}, \mathrm{MAAP}}$ & Mass concentration of light absorbing carbon measured by MAAP & 4 \\
\hline$\rho_{\mathrm{LAC}}=1.5 \mathrm{~g} \mathrm{~cm}^{-3}$ & Density of light absorbing carbon & 11 \\
\hline$n_{\text {less }- \text { abs }}=1.53$ & Real part of refractive index of less absorbing components & 0.5 \\
\hline$i_{\text {less }- \text { abs }}=1 \mathrm{e}-6$ & Imaginary part of refractive index of less absorbing components & 0 \\
\hline$n_{\mathrm{LAC}}=1.75$ & Real part of refractive index of light absorbing carbon & 4 \\
\hline$i_{\mathrm{LAC}}=0.55$ & Imaginary part of refractive index of light absorbing carbon & 6.6 \\
\hline
\end{tabular}

Table 4. Average relative standard deviations of the calculated $\sigma_{\mathrm{sp}}$ and $\sigma_{\text {bsp }}$ yielded from the Monte Carlo simulation. EXT, CS-INT and H-INT denote the mixing state of external, core-shell internal and homogeneously internal, respectively.

\begin{tabular}{lrrrrrrr}
\hline & \multicolumn{3}{c}{ Standard deviation of $\sigma_{\text {sp }}(\%)$} & & \multicolumn{3}{c}{ Standard deviation of $\sigma_{\text {bsp }}(\%)$} \\
\cline { 2 - 3 }$\lambda(\mathrm{nm})$ & EXT & CS-INT & H-INT & & EXT & CS-INT & H-INT \\
\hline 450 & 8.01 & 8.66 & 8.68 & & 6.85 & 7.18 & 7.87 \\
550 & 8.07 & 8.69 & 8.70 & & 6.96 & 7.26 & 7.82 \\
700 & 7.99 & 8.55 & 8.55 & & 7.26 & 7.52 & 8.02 \\
\hline
\end{tabular}

calculated and are listed in Table 5. For all the three wavelengths, more than $99 \%$ data records of $\sigma_{\mathrm{sp}}$ satisfied the closure criterion, whereas for $\sigma_{\mathrm{bsp}}$, the fractions are a little lower, but are still above $96 \%$.

In conclusion, considering the uncertainties, most of the measured $\sigma_{\mathrm{sp}}$ and $\sigma_{\mathrm{bsp}}$ agree with the values calculated with a modified Mie model using measured particle number size distributions and light-absorbing carbon concentrations, confirming a good quality of the data set.

\subsection{Truncation and non-Lambertian error correction for TSI 3563 nephelometer}

As mentioned in Sect. 2.2, the $\sigma_{\mathrm{sp}}$ and $\sigma_{\mathrm{bsp}}$ measured by TSI 3563 nephelometer contain systematic errors due to angular and wavelength non-idealities. Two factors contribute to the angular non-idealities: the truncation error (i.e. the geometrical blockage of near-forward/backward-scattered light) and the non-Lambertian error (i.e. the slightly non-cosine weighted intensity distribution of illumination light provided by the opal glass diffusor). These errors need to be considered because they can typically cause a bias of about $10 \%$ in the measured $\sigma_{\mathrm{sp}}$ (Müller et al., 2009). Other errors, such as wavelength non-idealities are of minor importance and are thus neglected. To correct the measurements, a correction
Table 5. The fractions of the measured $\sigma_{\mathrm{sp}}$ and $\sigma_{\mathrm{bsp}}$ satisfying the closure criterion in the total amount of the measured data, considering the uncertainties of both the measurements and calculations.

\begin{tabular}{ccc}
\hline$\lambda(\mathrm{nm})$ & $\sigma_{\mathrm{sp}}$ & $\sigma_{\mathrm{bsp}}$ \\
\hline 450 & $99.26 \%$ & $97.80 \%$ \\
550 & $99.33 \%$ & $98.67 \%$ \\
700 & $99.14 \%$ & $96.15 \%$ \\
\hline
\end{tabular}

factor is defined as

$C=\frac{\sigma_{\mathrm{sp} / \mathrm{bsp}, \text { true }}}{\sigma_{\mathrm{sp} / \mathrm{bsp}, \text { neph }}}$,

where $\sigma_{\mathrm{sp} / \mathrm{bsp}, \text { true }}$ is the theoretical true value which can be calculated with a regular Mie model. In contrast, $\sigma_{\mathrm{sp} / \mathrm{bsp}, \text { neph }}$ is the measured value which can be derived from the modified Mie model mentioned as in Sect. 2.2. Having the factor $C$ available, the measured values can be corrected by multiplying $C$.

Equation (5) shows that the direct approach to obtain $C$ would be to calculate $\sigma_{\mathrm{sp}} / \sigma_{\mathrm{bsp}}$ with both regular and modified Mie model using the measured particle number size distribution. In the case of lacking particle number size distribution measurements, the method developed by Anderson and Ogren (1998) has been widely applied. In this method, $C$ for $\sigma_{\text {sp }}\left(C_{\mathrm{sp}}\right)$ is constrained by the scattering Ångström exponent $(\alpha)$ obtained from the nephelometer measurement itself, while $C$ for $\sigma_{\mathrm{bsp}}\left(C_{\mathrm{bsp}}\right)$ is constant. $C_{\mathrm{sp}}$ is assumed to be a linear function of $\alpha$, namely $C_{\mathrm{sp}}=a_{1}+a_{2} \cdot \alpha$. The parameters $a_{1}$ and $a_{2}$ are determined beforehand with the Mie model and a large number of assumed bimodal lognormal particle number size distributions (see Anderson and Ogren, 1998). Different values of $a_{1}$ and $a_{2}$ are respectively given for no size cut and sub-micron particles at the three wavelengths. 

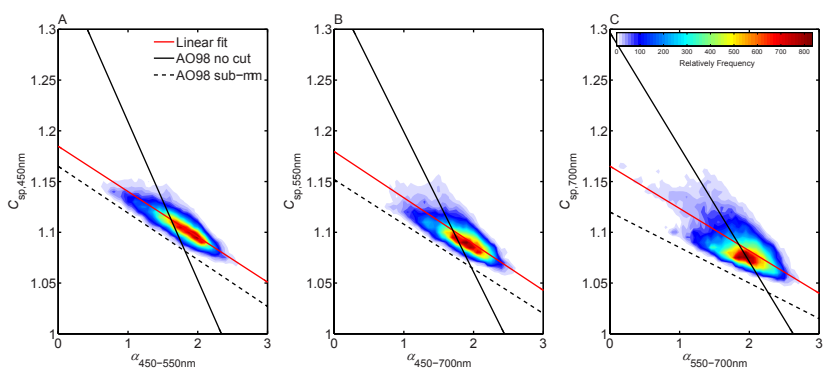

Figure 3. Relationships between calculated $C_{\mathrm{sp}}$ and measured $\alpha$ for the three operating wavelengths of TSI 3563 nephelometer. The red straight lines represent the linear regression of the data. To visualize the data distribution, the counts of data points are displayed as an intensity graph.

Having no complete particle number size distributions available for 2007, we decided to use Anderson's correction method for the 4-year nephelometer data set. However, to check whether the parameters $a_{1}$ and $a_{2}$ given in Anderson and Ogren (1998) were appropriate for Melpitz, the particle number size distributions measured from 2008 to 2010 were used to calculate alternative $C_{\mathrm{sp}}$ and $C_{\mathrm{bsp}}$ via the Mie model. In the calculation, the refractive indices were estimated as mentioned in Sect. 2.2 and the mixing state of the aerosol was assumed as external. Figure 3 displays the calculated $C_{\mathrm{sp}}$ versus nephelometer-derived $\alpha$ at three wavelengths. The red line is the result of the linear fit between $C_{\mathrm{sp}}$ and $\alpha$. It is interesting that for all three wavelengths, the fitting result does not match the formula for the no-cut case in Anderson's method (the black solid line in Fig. 3). It is close to the sub- $\mu \mathrm{m}$ case in Anderson's method (black dashed line in Fig. 3) but with different intercept. A possible reason might be that the statistical characters of the aerosol number size distributions in Melpitz differ from those used by Anderson and Ogren (1998) when developing their method.

To better understand the mismatch between the $C_{\mathrm{sp}}$ yielded from Anderson's parameterization and from Mie calculation, $C_{\mathrm{sp}}$ was calculated based on aerosol number size distributions measured in another station, Leipzig-TROPOS, from 1 January 2010 to 31 December 2010. LeipzigTROPOS is a suburban station representative of the urban background aerosol, which is also a part of network GUAN (German Ultrafine Aerosol Network; Birmili et al., 2009). With the same instrumentation, the measured data were processed according to Sect. 2.1, and $1 \mathrm{~h}$ data were used. The $C_{\mathrm{sp}}$ was then calculated with each individual aerosol size distribution with the same method applied to Melpitz data. Figure $4 \mathrm{~b}$ shows the calculated $C_{\mathrm{sp}}$ at $550 \mathrm{~nm}$ versus $\alpha$. The colour of data points denotes the volume fraction of submicron aerosol ( $\left.f_{\mathrm{V} \text {-submicron }}\right)$ calculated with the corresponding aerosol size distribution. As a comparison, the results of Melpitz in the same time period are also shown in Fig. 4a. It can be found in Fig. 4 that the locations of the data points
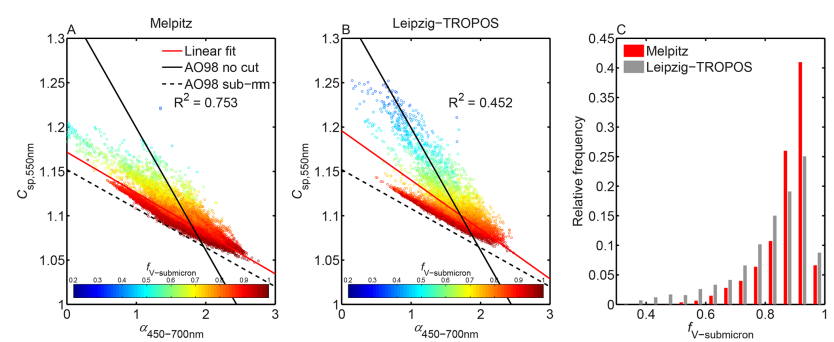

Figure 4. Relationships between calculated $C_{\mathrm{sp}}$ and measured $\alpha_{450-700 \mathrm{~nm}}$ at Melpitz (A) and Leipzig-TROPOS (B). Colours of dots denote the corresponding volume fraction of submicron aerosol to total aerosol. The red straight lines represent the linear regression of the data. (C) The relative frequency distributions of the volume fraction of submicron aerosol in Melpitz and Leipzig-TROPOS.

Table 6. Parameters for the linear function of $C_{\mathrm{sp}}$, and the average $C_{\text {bsp }}$ used in this study.

\begin{tabular}{cccc}
\hline$\lambda(\mathrm{nm})$ & $a_{1}$ & $a_{2}$ & $C_{\mathrm{bsp}}$ \\
\hline 450 & 1.185 & -0.0446 & 0.978 \\
550 & 1.180 & -0.0456 & 0.979 \\
700 & 1.165 & -0.0417 & 0.984 \\
\hline
\end{tabular}

strongly depend on $f_{\mathrm{V} \text {-submicron }}$. They are close to the submicron case in Anderson's method (black dashed line) in both Melpitz and Leipzig-TROPOS when $f_{\mathrm{V} \text {-submicron }}$ is higher than 0.8. And the points in Leipzig-TROPOS follow well with the no-cut case in Anderson's method (the black solid

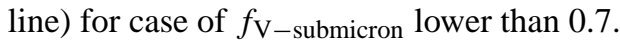

The $C_{\mathrm{sp}}$ mainly depends on the shape of aerosol number size distributions. In Anderson and Ogren (1998), they assumed a series of bimodal log-normal aerosol number size distributions, with geometric mean diameter set within 200 $400 \mathrm{~nm}$ and $2-4 \mu \mathrm{m}$ for the two modes, respectively. These generated aerosol number size distributions were then used for calculating $C_{\mathrm{sp}}$ and $\alpha$ with Mie model. And the parameters $a_{1}$ and $a_{2}$ were determined by linear fits of calculated $C_{\mathrm{sp}}$ and $\alpha$. However, these assumed bimodal log-normal distributions may be not representative of the aerosol in the region of our measurement. Due to the active secondary aerosol production and anthropogenic aerosol emission in the region, aerosol optical properties are dominated by the submicron aerosol in Melpitz. Figure $4 \mathrm{c}$ shows the relative fre-

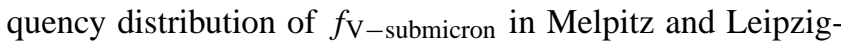
TROPOS. It can be seen that submicron aerosol takes more than $70 \%$ of the total aerosol volume in most cases in Mel-

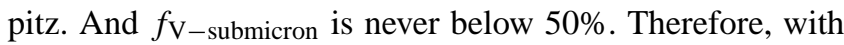
the domination of submicron aerosol, the relationship between $C_{\mathrm{sp}}$ and $\alpha$ is similar with submicron case rather than no-cut case in Anderson's method. For Leipzig-TROPOS, the frequency distribution of $f_{\mathrm{V} \text {-submicron }}$ is broader than that in Melpitz. There are a number of cases with $f_{\mathrm{V} \text {-submicron }}$ 
Table 7. Statistic values of dry-state aerosol optical properties for the period from 2007 to 2010 (based on hourly average data).

\begin{tabular}{lrrrrrrr}
\hline Parameter & $\lambda(\mathrm{nm})$ & Mean & S.D. & Median & Max. & Min. & Numbers \\
\hline \multirow{3}{*}{$\sigma_{\text {sp }}\left(\mathrm{Mm}^{-1}\right)$} & 450 & 73.11 & 73.30 & 50.83 & 832.40 & 1.10 & 31581 \\
& 550 & 53.61 & 58.64 & 34.70 & 666.74 & 0.76 & 31581 \\
& 700 & 35.17 & 41.77 & 21.25 & 455.72 & 0.46 & 31581 \\
\hline & 450 & 7.45 & 6.85 & 5.59 & 78.78 & 0.12 & 31581 \\
$\sigma_{\text {bsp }}\left(\mathrm{Mm}^{-1}\right)$ & 550 & 5.97 & 5.69 & 4.39 & 67.47 & 0.07 & 31581 \\
& 700 & 5.12 & 5.19 & 3.63 & 60.57 & 0.04 & 31581 \\
\hline$\sigma_{\text {ap }}\left(\mathrm{Mm}^{-1}\right)$ & 637 & 5.67 & 6.95 & 3.52 & 85.81 & 0.12 & 33624 \\
$\omega$ & 637 & 0.871 & 0.051 & 0.877 & 0.994 & 0.517 & 30842 \\
$b$ & 550 & 0.125 & 0.022 & 0.124 & 0.258 & 0.075 & 31581 \\
$\alpha$ & $450-550$ & 1.72 & 0.38 & 1.77 & 3.02 & 0.03 & 31581 \\
& $550-700$ & 1.85 & 0.41 & 1.91 & 4.72 & 0.10 & 31581 \\
\hline
\end{tabular}

lower than $70 \%$. For these cases, the relationship between $C_{\mathrm{sp}}$ and $\alpha$ match well with the no-cut case in Anderson's method.

Therefore, if the aerosol volume concentration is always dominated by submicron aerosol, as in the case of Melpitz, the method developed by Anderson and Ogren (1998) is applicable with some other values of parameters $a_{1}$ and $a_{2}$. However, if the volume concentration is sometimes also dominated by coarse aerosol, as in the case of LeipzigTROPOS, it is impossible to use $C_{\mathrm{sp}}=a_{1}+a_{2} \cdot \alpha$ to fit all the data points well. As shown in Fig. 4b, the fit result is not representative of all the data points, and the $R^{2}$ is only 0.452 . The only solution for this case is to calculate $C_{\mathrm{sp}}$ with Mie model and aerosol number size distributions measured parallel.

For the rest of this study, the method developed by Anderson and Ogren (1998) was applied to calculate $C_{\mathrm{sp}}$. The parameters $a_{1}$ and $a_{2}$ derived from the linear fit of calculated $C_{\mathrm{sp}}$ and $\alpha$ were used in the correction for the 4-year nephelometer data. In other words, we used Anderson's method but with a new group of parameters determined by ourselves. The new parameters are listed in Table 6 . The calculated $C_{\mathrm{bsp}}$ for the three wavelengths are also shown.

\subsection{Overview of long-term measurements}

Statistics of dry-state aerosol $\sigma_{\mathrm{sp}}, \sigma_{\mathrm{bsp}}$ and $\sigma_{\mathrm{ap}}$, as well as the calculated single scattering albedo $(\omega)$, hemispheric backscattering fraction $(b)$ and scattering Ångström exponent $(\alpha)$ are given in Table 7 based on hourly average data for the period of 2007 to 2010. In Melpitz, the mean $\sigma_{\mathrm{sp}}$ and $\sigma_{\mathrm{bsp}}$ at $550 \mathrm{~nm}$ are $53.61 \pm 58.64 \mathrm{Mm}^{-1}$ and $5.97 \pm 5.69 \mathrm{Mm}^{-1}$, respectively. The mean $\sigma_{\text {ap }}$ at $637 \mathrm{~nm}$ is $5.67 \pm 6.95 \mathrm{Mm}^{-1}$. The ratio between the maximum and minimum monthly mean $\sigma_{\mathrm{sp}}$ at $550 \mathrm{~nm}$ is 8 and even reaches up to 10 for the $\sigma_{\text {ap }}$ at $637 \mathrm{~nm}$, implying large variations for the monthly aerosol scattering and absorption levels. Comparing with the long-term measurements at the regional background stations in other continents, the average $\sigma_{\mathrm{sp}}$ measured in Melpitz is slightly higher than that measured at the rural station Lamont in the middle of America (1997-2000) (Delene and Ogren, 2002), and is only about $30 \%$ of that measured in the Global Atmosphere Watch regional station Shangdianzi in North China (2003-2004) (Yan et al., 2008). An absorption Angström exponent of -1 was assumed in the wavelength adjustment of $\sigma_{\text {ap }}$ for the comparison. The average $\sigma_{\text {ap }}$ measured in Melpitz is about 2.5 times that measured at Lamont in the middle of America (1997-2000) (Delene and Ogren, 2002), and is about $40 \%$ of that measured in Shangdianzi in North China (2003-2004) (Yan et al., 2008).

The single scattering albedo, defined as $\omega=$ $\sigma_{\mathrm{sp}} /\left(\sigma_{\mathrm{sp}}+\sigma_{\mathrm{ap}}\right)$, is important for the estimation of aerosol direct radiative forcing. A small error in this parameter may change the sign of aerosol radiative forcing (Takemura et al., 2002). To calculate $\omega$ in Melpitz, the measured $\sigma_{\mathrm{sp}}$ and $\sigma_{\mathrm{ap}}$ should be corrected to the same wavelength. Lacking information on the wavelength dependency of $\sigma_{\mathrm{ap}}$, we decided to adjust $\sigma_{\mathrm{sp}}$ to $637 \mathrm{~nm}$ using the scattering Ångström exponent calculated from $\sigma_{\mathrm{sp}}$ at 550 and $700 \mathrm{~nm}$. The mean $\omega$ at $637 \mathrm{~nm}$ for dry-state aerosol in Melpitz is $0.871 \pm 0.051$. It should be noted that the $\sigma_{\mathrm{sp}}$ and $\sigma_{\mathrm{ap}}$ at Melpitz were measured at relatively dry conditions ( $\mathrm{RH}<40 \%)$. The ambient $\omega$ may be higher due to the hygroscopic growth of aerosol. As an intensive aerosol property which is important for aerosol direct radiative forcing, it is of great value to compare the $\omega$ in Melpitz with those measured in other regions. Table 8 lists the average $\omega$ obtained in other long-term in situ measurement around the world. With different instrumentation, the $\omega$ was given at different wavelengths in different studies. To compare $\omega$ calculated at different wavelengths, the average $\omega$ in Melpitz was adjusted to several wavelengths based on the average scattering Ångström exponent listed in Table 7 and an absorption Ångström exponent of -1 , as shown in Table 8. It can be seen that the average $\omega$ in Melpitz is obviously lower than those obtained in marine sites (Mace Head, Sable 

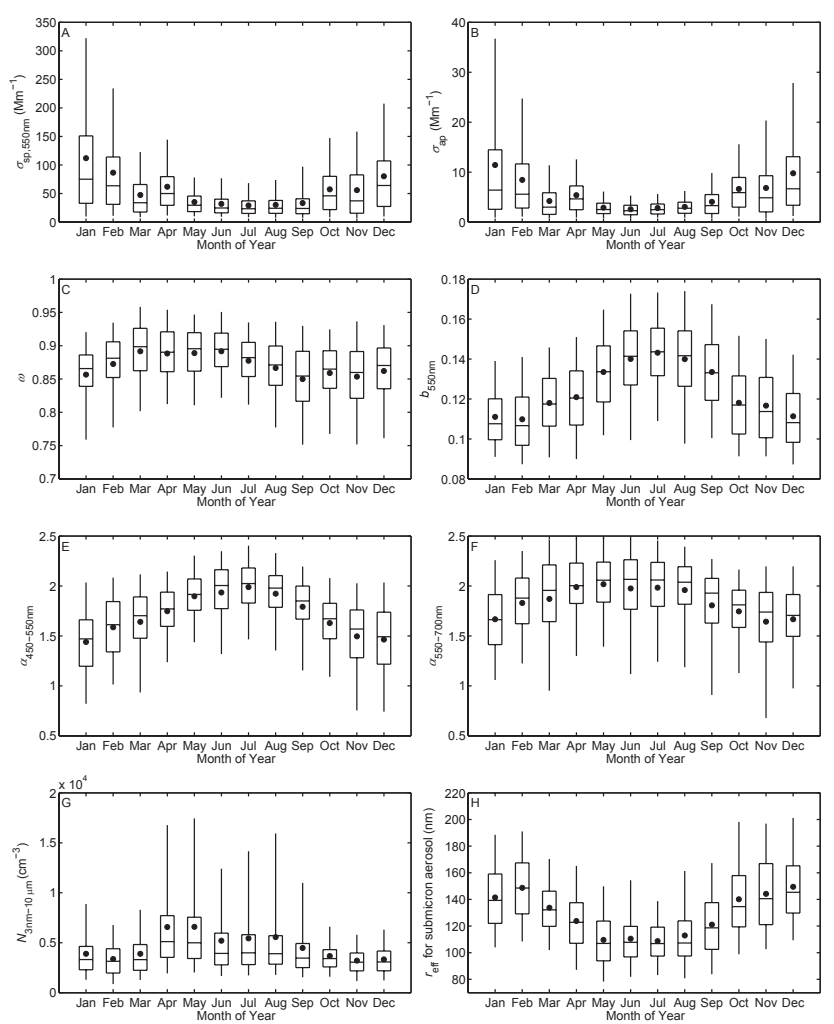

Figure 5. Annual variations of aerosol scattering coefficient (A), absorption coefficient (B), single scattering albedo (C), hemispheric backscattering fraction (D), Ångström exponent at 450-550 nm (E) and at 550-700 nm (F), aerosol total number concentration (G), and the effective radius of submicron aerosol $(\mathbf{H})$. For each panel, the boxes and whiskers denote the 5, 25, 50, 75 and 95 percentiles, while the dots denote the mean values.

Island and Barrow) in which the aerosol optical properties are dominated by sea salt, and is similar as those measured in regional background sites (Bondville, Hohenpeissenberg, K-Puszta and Shangdianzi) and the Mediterranean site (Finokalia) which influenced by anthropogenic and/or biomass burning activities.

The $b$ was calculated according to $b=\sigma_{\mathrm{bsp}} / \sigma_{\mathrm{sp}}$ using measured $\sigma_{\mathrm{sp}}$ and $\sigma_{\mathrm{bsp}}$. The mean value of $b$ at $550 \mathrm{~nm}$ is $0.125 \pm 0.022$. The $\alpha$ was calculated with measured $\sigma_{\mathrm{sp}}$ at different wavelengths with $\alpha=\ln \left(\sigma_{\lambda 1} / \sigma_{\lambda 2}\right) / \ln \left(\lambda_{2} / \lambda_{1}\right)$. The average $\alpha$ calculated at wavelengths of 450 and $550 \mathrm{~nm}$ is $1.72 \pm 0.38$.

\subsection{Annual variations of aerosol optical properties}

The average annual variations of dry-state aerosol optical properties, as well as the aerosol total number concentration $\left(N_{3 \mathrm{~nm}}-10 \mu \mathrm{m}\right)$ and the effective radius $\left(r_{\mathrm{eff}}\right)$ of submicron aerosol in Melpitz are shown in Fig. 5. It can be seen that annual variations can be found in all the dry aerosol optical properties. Some of them show evident annual patterns.
The $\sigma_{\mathrm{sp}}$ and $\sigma_{\mathrm{ap}}$ have nearly the same variation pattern, with relatively higher values in winter and lower values in summer. The mean values of $\sigma_{\mathrm{sp}}$ and $\sigma_{\mathrm{ap}}$ are always higher than the median values, especially in winter, indicating that heavier pollution events rather occur in winter than in summer. The annual variations of $\sigma_{\mathrm{sp}}$ and $\sigma_{\mathrm{ap}}$ are mainly determined by the annual variations of the boundary layer height, the local emissions and pollutants transport. In winter, the local emission is higher due to a larger amount of fossil fuel combustion. The wintertime shallow mixing layer favours the accumulation of aerosol pollutants, and thus causes a higher level of $\sigma_{\mathrm{sp}}$ and $\sigma_{\mathrm{ap}}$. Moreover, the $\sigma_{\mathrm{sp}}$ and $\sigma_{\mathrm{ap}}$ may be also influenced by the air masses related to middle- or largescale atmospheric motion, and thus represent wide possibility distributions in winter. In summer, the boundary layer is more unstable due to surface heating and causes turbulence and vertical mixing, which results in a dilution effect for pollutant. Therefore, $\sigma_{\mathrm{sp}}$ and $\sigma_{\mathrm{ap}}$ in summer are at a relatively low level and with small variations. Precipitation scavenging is an important way to clean aerosol particles out of the atmosphere (Buat-Ménard and Duce, 1986; Jaffrezo and Colin, 1988). The precipitation measured near Melpitz shows that the accumulated precipitation in summer is approximately two times as much as that in winter. The stronger precipitation scavenging of aerosol particles may also be an important reason of the low level of $\sigma_{\mathrm{sp}}$ and $\sigma_{\mathrm{ap}}$ in summer.

The $\omega$ only shows slight annual variations, with high values in spring and summer, and low values in autumn and winter. This annual pattern might be mainly caused by the variation of regional emission and the secondary aerosol formation. Figure 6 shows the average diurnal variation of aerosol number size distribution in the four seasons, based on the measurements of TDMPS from 2008 to 2010. It can be seen that the formation and growth of nucleation mode particles are evident in daytime in spring and summer. In these two seasons, secondary aerosol productions via photochemistry processes are efficient and results in a large fraction of less absorbing components such as organic matter and sulfate in particulate matters (Poulain et al., 2011a), hence yielding a relatively higher level of $\omega$. The "banana shape" is less pronounced in autumn and disappears in winter, indicating the inhibition of secondary aerosol production in these two seasons, thus resulting in a relatively lower level of $\omega$. The annual variation of the emission rate of $\mathrm{BC}$ may also contribute to the variation of $\omega$. In winter, the local emission of $\mathrm{BC}$ is higher due to a larger amount of fossil fuel combustion. It was also found that the residential wood burning during the cold seasons has a significant contribution on the elemental carbon in Europe (Genberg et al., 2013). The higher emission of $\mathrm{BC}$ and less activity of aerosol aging and secondary aerosol formation causes a lower $\omega$ in winter.

The $\alpha$ is mainly determined by the shape of the aerosol number size distribution: $\alpha$ smaller than 1 indicates that the size distribution is dominated by coarse mode, and $\alpha$ larger than 2 indicates that fine-mode particles dominate the size 
Table 8. Average $\omega$ obtained in other long-term in situ measurement around the world.

\begin{tabular}{|c|c|c|c|c|c|c|c|}
\hline$\omega$ & $\lambda(\mathrm{nm})$ & $\begin{array}{l}\text { Station and } \\
\text { country }\end{array}$ & Altitude (m) & $\begin{array}{l}\text { Type of } \\
\text { station }\end{array}$ & Period & Instrumentation & Reference \\
\hline $\begin{array}{l}0.871 \pm 0.051 \\
0.891 @ 550 \mathrm{~nm} \\
0.893 @ 530 \mathrm{~nm} \\
0.894 @ 525 \mathrm{~nm}\end{array}$ & 637 & $\begin{array}{l}\text { Melpitz, } \\
\text { Germany }\end{array}$ & 87 & $\begin{array}{l}\text { regional } \\
\text { background }\end{array}$ & $2007-2010$ & $\begin{array}{l}\text { MAAP, Thermo; } \\
3563 \text { Nephelometer, TSI }\end{array}$ & This study \\
\hline $0.88 \pm 0.05$ & 525 & $\begin{array}{l}\text { Shangdianzi, } \\
\text { China }\end{array}$ & 293 & $\begin{array}{l}\text { regional } \\
\text { background }\end{array}$ & Sep 2003-Jan 2005 & $\begin{array}{l}\text { AE31 Aethalometer, Magee Scientific; } \\
\text { M9003 Nephelometer, EcoTech }\end{array}$ & Yan et al. (2008) \\
\hline $0.92 \pm 0.04$ & 530 & $\begin{array}{l}\text { K-Puszta, } \\
\text { Hungary }\end{array}$ & 125 & $\begin{array}{l}\text { regional } \\
\text { background }\end{array}$ & 1998-1999 & PSAP, Radiance Research; Nephelometer, & $\begin{array}{l}\text { Molnár and } \\
\text { Mészáros (2001) }\end{array}$ \\
\hline $0.906 \pm 0.067$ & 550 & $\begin{array}{l}\text { Bondville, } \\
\text { US }\end{array}$ & 230 & $\begin{array}{l}\text { regional } \\
\text { background }\end{array}$ & Sep 1996-Sep 2000 & $\begin{array}{l}\text { PSAP, Radiance Research; } \\
3563 \text { Nephelometer, TSI }\end{array}$ & $\begin{array}{l}\text { Delene and } \\
\text { Ogren (2002) }\end{array}$ \\
\hline $0.932 \pm 0.051$ & 550 & Lamont, US & 315 & $\begin{array}{l}\text { regional } \\
\text { background }\end{array}$ & Apr 1997-Sep 2000 & $\begin{array}{l}\text { PSAP, Radiance Research; } \\
3563 \text { Nephelometer, TSI }\end{array}$ & $\begin{array}{l}\text { Delene and } \\
\text { Ogren (2002) }\end{array}$ \\
\hline $0.953 \pm 0.038$ & 550 & $\begin{array}{l}\text { Sable Island, } \\
\text { US }\end{array}$ & 5 & marine & Nov 1994-Apr 2000 & $\begin{array}{l}\text { PSAP, Radiance Research; } \\
3563 \text { Nephelometer, TSI }\end{array}$ & $\begin{array}{l}\text { Delene and } \\
\text { Ogren (2002) }\end{array}$ \\
\hline $0.959 \pm 0.040$ & 550 & Barrow, US & 8 & marine & Oct $1997-$ Sep 2000 & $\begin{array}{l}\text { PSAP, Radiance Research; } \\
3563 \text { Nephelometer, TSI }\end{array}$ & $\begin{array}{l}\text { Delene and } \\
\text { Ogren (2002) }\end{array}$ \\
\hline $0.89 \pm 0.04$ & 550 & $\begin{array}{l}\text { Finokalia, } \\
\text { Greece }\end{array}$ & 250 & marine & Mar 2001-Jun 2002 & $\begin{array}{l}\text { PSAP, Radiance Research; } \\
\text { M903 Nephelometer, Radiance Research }\end{array}$ & $\begin{array}{l}\text { Vrekoussis et } \\
\text { al. (2005) }\end{array}$ \\
\hline $0.941-0.997$ & 550 & $\begin{array}{l}\text { Mace Head, } \\
\text { Ireland }\end{array}$ & 5 & marine & Jan 2000-Dec 2002 & $\begin{array}{l}\text { AE8/AE9 Aethalometer, Magee Scientific; } \\
\text { 3563/3551 Nephelometer, TSI }\end{array}$ & $\begin{array}{l}\text { Jennings et } \\
\text { al. (2003) }\end{array}$ \\
\hline $0.81(0.74-0.86)$ & 525 & $\begin{array}{l}\text { Mukteshwar, } \\
\text { India }\end{array}$ & 2180 & mountain & Sep 2005-Sep 2007 & $\begin{array}{l}\text { AE31 Aethalometer, Magee Scientific; } \\
\text { M9003 Nephelometer, EcoTech }\end{array}$ & $\begin{array}{l}\text { Hyvärinen et } \\
\text { al. (2009) }\end{array}$ \\
\hline $0.85-0.91$ & & $\begin{array}{l}\text { Hohenpeissenberg } \\
\text { Germany }\end{array}$ & 1000 & mountain & 1999-2005 & $\begin{array}{l}\text { Aethalometer, Magee Scientific; MAAP, } \\
\text { Thermo; } 3563 \text { Nephelometer, TSI }\end{array}$ & Kaminski (2006) \\
\hline $0.84 \pm 0.09$ & 637 & $\begin{array}{l}\text { Puijo, } \\
\text { Finland }\end{array}$ & 150 & semiurban & Sep 2006-Sep 2010 & MAAP, Thermo; 3563 Nephelometer, TSI & $\begin{array}{l}\text { Leskinen et } \\
\text { al. (2012) }\end{array}$ \\
\hline $0.86 \pm 0.08$ & 637 & $\begin{array}{l}\text { Central } \\
\text { Amazonia, } \\
\text { Brazil }\end{array}$ & 110 & tropical forest & Feb 2008-Feb 2011 & MAAP, Thermo; 3563 Nephelometer, TSI & Rizzo et al. (2013) \\
\hline
\end{tabular}

distribution (Eck et al., 1999; Westphal and Toon, 1991). Therefore, the annual pattern of $\alpha$ can be explained by the variation of aerosol number size distributions. In spring and summer, new particle formation events can be found on $40 \%$ of the days in Melpitz, as shown in Fig. 6. During such periods, nucleation mode concentrations can increase within a short time by $>1$ order of magnitude, occasionally exceeding $10^{5} \mathrm{~cm}^{-3}$ (Birmili et al., 2001). This also can be found in the annual variation of aerosol total number concentration and the effective radius of submicron aerosol in Fig. 5. Due to the active new particle formation and growth in spring and summer, the aerosol total number concentration shows higher averages and more variability than in autumn and winter, and the effective radius of submicron aerosol shows evidently lower levels. These high concentrations of small particles during new particle formation in spring and summer cause a high level of $\alpha$, thus resulting in higher average $\alpha$ compared to that in autumn and winter.

One should also note that the $\alpha$ for the two wavelength pairs show some difference in their annual patterns: $\alpha_{450-550 \mathrm{~nm}}$ in summer is at the similar level as $\alpha_{550-700 \mathrm{~nm}}$, while in winter $\alpha_{450-550 \mathrm{~nm}}$ is lower than $\alpha_{550-700 \mathrm{~nm}}$. $\alpha_{450-550 \mathrm{~nm}}$ therefore shows a more obvious annual varia-

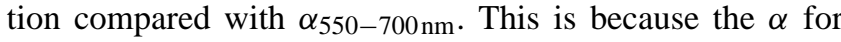
different wavelength pairs has different response on the variation of aerosol number size distribution. Figure $7 \mathrm{c}$ and $\mathrm{e}$ show the measured $\alpha_{450-550 \mathrm{~nm}}$ and $\alpha_{550-700 \mathrm{~nm}}$ versus the effective radius of submicron aerosol. An inverse relationship can be seen between these two parameters, which accords with Schuster et al. (2006). It can be found that $\alpha_{450-550 \mathrm{~nm}}$ is more sensitive to the variation of the effective radius of

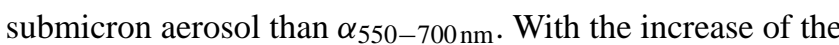
effective radius of submicron aerosol, $\alpha_{450-550 \mathrm{~nm}}$ decreases with a steeper slope than $\alpha_{550-700 \mathrm{~nm}}$. Therefore, in the cases of $r_{\text {eff }}$ lower than $120 \mathrm{~nm}$ (i.e. in summer), the two $\alpha$ are at a similar level, while in the case of $r_{\text {eff }}$ higher than $140 \mathrm{~nm}$ (i.e. in winter), $\alpha_{450-550 \mathrm{~nm}}$ is lower than $\alpha_{550-700 \mathrm{~nm}}$.

An evident annual pattern can be found in $b$, with higher values in summer than in winter. This annual pattern can be attributed to the variation of both the number size distribution and the mixing state of particles. As mentioned above, due to the secondary aerosol formation in spring and summer, a significant nucleation mode can be usually found and causes a low level of the effective radius of submicron aerosol. As shown in Fig. 7a, there is a significant inverse relationship between $b$ and the effective radius of submicron aerosol, which 

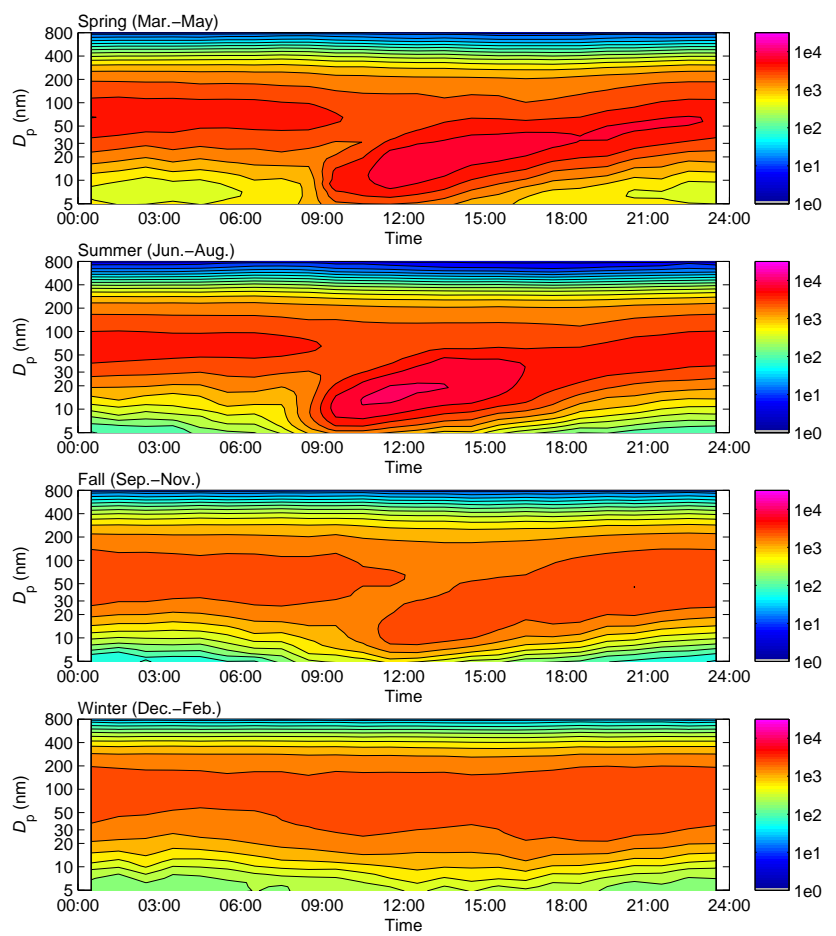

Figure 6. Average diurnal evolution of the aerosol number size distribution in the four seasons, based on TDMPS measurement between 2008 and 2010.

accords with Collaud Coen et al. (2007). The low level of the effective radius of submicron aerosol therefore results in a high level of $b$ in summer. In addition, it was found that the morphology of a $\mathrm{BC}$ core surrounded by a less absorbing shell would result in a much higher $b$ than the external mixture of the same amount of both components (Ma et al., 2012). In spring and summer, due to the active photochemical aging processes, $\mathrm{BC}$ is closer to the morphology of coreshell than in winter, and thus causes a higher level of $b$. To better study the dependence of $b$ on particle size and the mixing state of $\mathrm{BC}$, the single particle hemispheric backscattering fraction was calculated based on the Mie model. In the calculation, two mixing states were assumed: BC externally mixed and $\mathrm{BC}$ coated with less absorbing components. The volume fraction of $\mathrm{BC}$ was set to 0.058 , which is the average value during the whole period. For more details of the calculation see Sect. 2.2. Results are shown in Fig. 8, where it can be seen that $b$ shows a high dependence on the particle size. Especially in the range of 100 to $300 \mathrm{~nm}, b$ drops down steeply with the increase of particle size. After $300 \mathrm{~nm}$, $b$ fluctuates with increased size. This result explains the inverse relationship between $b$ and the effective radius of submicron aerosol. One should note that the mixing state of BC also influences $b$. The $b$ calculated based on core-shell mixture is higher than that calculated based on external mixture for almost all sizes between $10 \mathrm{~nm}$ to $10 \mu \mathrm{m}$. However, the influence of mixing state is less than that of the particle size.
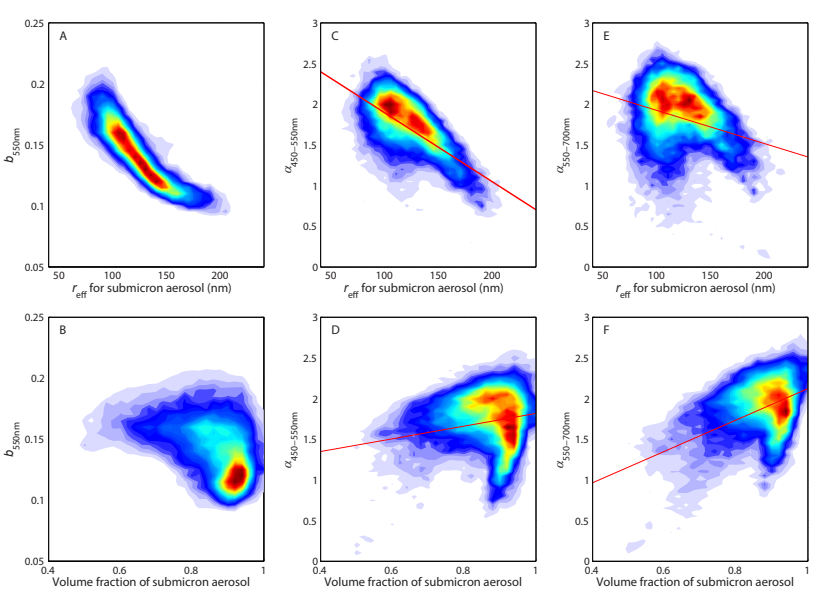

Figure 7. Relationships between $b_{550 \mathrm{~nm}}$ and the effective radius of submicron aerosol (A), $b_{550 \mathrm{~nm}}$ and the volume fraction of sub-

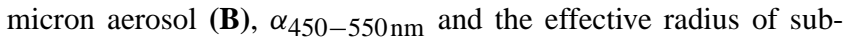

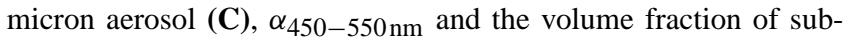

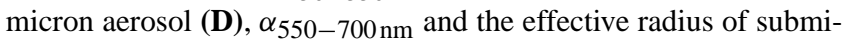

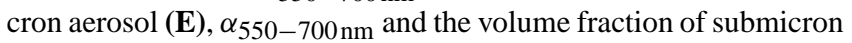
aerosol (F). Red straight lines represent the linear regression of the data. To visualize the data distribution, the counts of data points are displayed as an intensity graph.

\subsection{Diurnal variations of aerosol optical properties}

Figure 9 shows the average diurnal variations of dry-state aerosol optical properties, the volume fraction and effective radius of submicron aerosol in warm season (April to September) and cold season (October to March) measured in Melpitz. Values of percentiles are not shown to facilitate better visualization of the data. Basically, all parameters show some diurnal patterns, with lower contrast compared with their annual variations.

The $\sigma_{\mathrm{sp}}$ and $\sigma_{\mathrm{ap}}$ shows similar diurnal patterns, with high values during night and low values during daytime. This can be mainly attributed to the diurnal variation of the boundary layer height. The developing of boundary layer during daytime causes a vertical mixing thus dilutes the pollutant near the surface. During night, new emitted aerosol accumulates in the shallow nocturnal boundary layer. $\sigma_{\mathrm{sp}}$ and $\sigma_{\mathrm{ap}}$ therefore remain at a relative high level. This effect is more active in warm season due to surface heating, thus causes a higher contrast between the values in daytime and nighttime than in cold season. The diurnal variation of aerosol emission is also important to explain the diurnal pattern of $\sigma_{\mathrm{sp}}$ and $\sigma_{\mathrm{ap}}$, especially in cold season. $\sigma_{\mathrm{ap}}$ shows an evident maxima around 21:00 LT in cold season, might stem from the increase of BC emission from residential wood burning at night (Poulain et al., 2011b). The high values of $\sigma_{\mathrm{sp}}$ and $\sigma_{\mathrm{ap}}$ in the morning might also be a reflection of the beginning of anthropogenic activities in the region.

Recalling the definition of $\omega$, the diurnal variation of $\omega$ seems to originate from the phase difference between the 


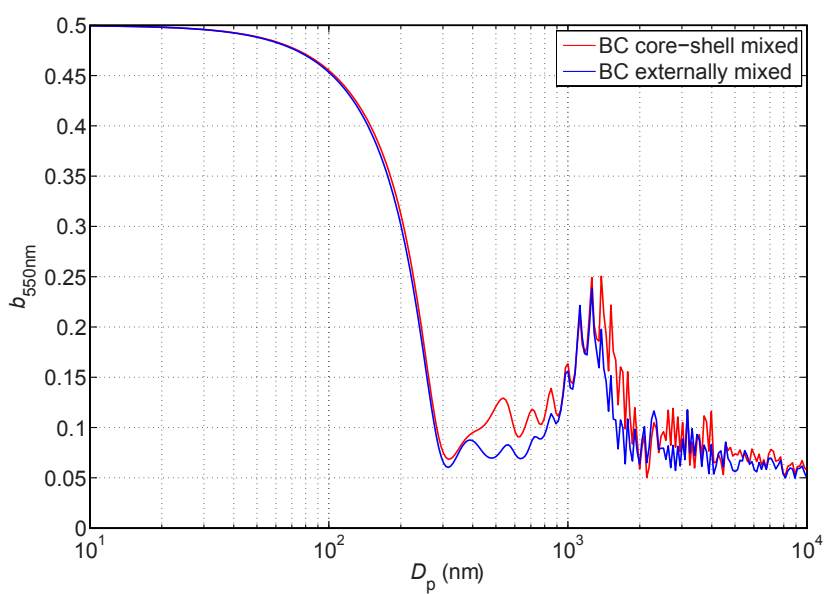

Figure 8. Single-particle hemispheric backscattering fraction calculated based on Mie model, assuming core-shell mixture (red line) and external mixture (blue line) of $\mathrm{BC}$ and light-scattering material.

diurnal variations of $\sigma_{\mathrm{sp}}$ and $\sigma_{\mathrm{ap}}$. Two drops in $\omega$ are evident after 06:00 and 15:00 LT, respectively, in the cold season (Fig. 9c). These decreases in $\omega$ correspond to the peaks in $\sigma_{\mathrm{ap}}$ around the same time. In the warm season, the diurnal patterns of $\sigma_{\mathrm{sp}}$ and $\sigma_{\mathrm{ap}}$ are more similar to each other, so $\omega$ shows less diurnal variability than in the cold season. The $\omega$ in the warm season shows a high level between 09:00 and 18:00 LT, mainly stemming from the enhancement of lightscattering aerosol from secondary aerosol formation and aging processes, which can also be found in the diurnal variation of aerosol number size distribution (Fig. 6).

As mentioned in Sect. 3.4, both $b$ and $\alpha$ are mainly determined by the shape of aerosol number size distribution. Thus their diurnal variations are highly correlated with the diurnal variations of the effective radius and volume fraction of submicron aerosol, as shown in Fig. 9. In the warm season, due to the aging processes and the mixing down of aged aerosol from aloft during the development of planetary boundary layer, $r_{\mathrm{eff}}$ increases before 09:00 LT. As a result, $\alpha$ and $b$ decrease and both reach their minimum at 09:00 LT. As shown in Fig. 6, the new particle formation begins at around 09:00 LT. Due to the formation and consequent growth of aerosol, $r_{\text {eff }}$ begins to decrease at 09:00 LT, and causes an increase of $\alpha$ and $b$. After 18:00 LT, $\alpha$ increases again with the increase of volume fraction of submicron aerosol. In the cold season, the secondary aerosol production and aging processes is less active. Therefore, the diurnal pattern of $\alpha$ and $b$ mentioned above can also be seen but with less contrast.

\subsection{Aerosol optical properties in different air masses}

In central Europe, synoptic-scale air masses can be an efficient concept to explain the concentrations of long-lived trace gas and aerosol species. The reason is that the air masses occurring in central Europe may differ significantly with re-
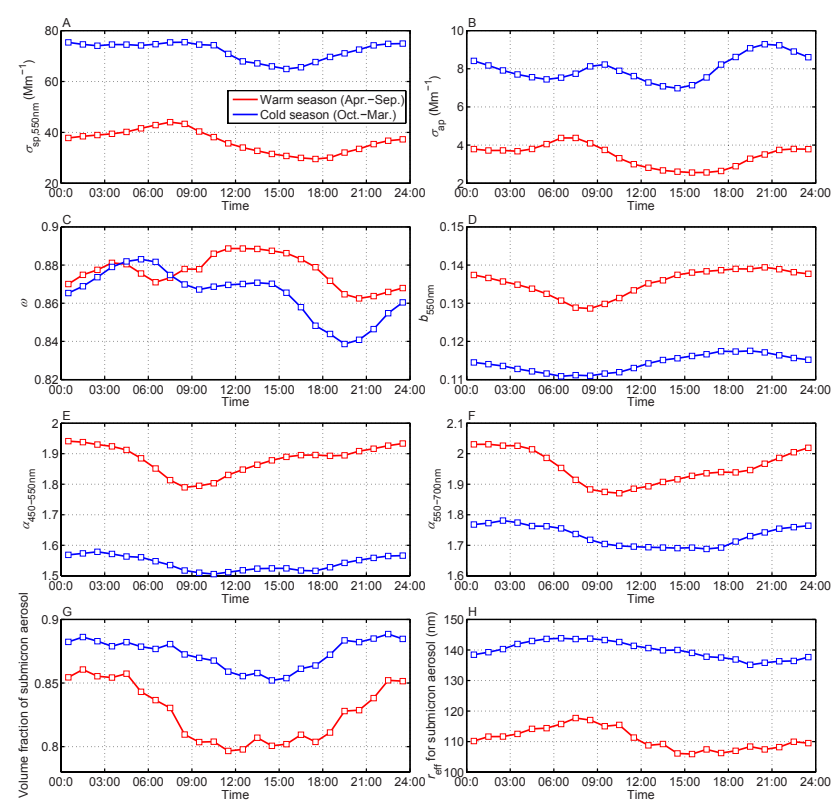

Figure 9. Average diurnal variations of aerosol scattering coefficient (A), absorption coefficient (B), single scattering albedo (C), hemispheric backscattering fraction (D), Ångström exponent at $450-550 \mathrm{~nm}(\mathbf{E})$ and at $550-700 \mathrm{~nm}(\mathbf{F})$, the volume fraction of submicron aerosol $(\mathbf{G})$, and the effective radius of submicron aerosol (H). For each panel, the red and blue lines represent the results of warm (April-September) and cold season (October-March), respectively.

spect to the type of their area of origin (ocean, marginal seas, continent), and the related meteorological properties (moisture content, degree of precipitation, stability). To assess the influence of such geographical factors on the aerosol optical properties at Melpitz, the $4 \mathrm{yr}$ data were grouped according to the daily BCLM air mass classification described in Sect. 2.3.

Figure 10 shows the average, median and various percentile values of aerosol optical properties for the 13 air mass types. As the BCLM scheme accounts for vertical stability (stable/neutral stratification), the air mass types in Fig. 10 are distinguished between those with more stable stratification (left) and those with more neutral stratification (right). As explained in Sect. 2.3, more stable stratification tends to occur in the cold season while more neutral stratification tends to prevail in the warm season. Within these two categories, the air masses are sorted according to a descending scattering coefficient $\sigma_{\text {sp }}$ at $550 \mathrm{~nm}$.

As an overall observation $\sigma_{\mathrm{sp}}$ and $\sigma_{\mathrm{ap}}$ tend to be higher in air masses of more stable stratification (cold season) compared to those with more neutral stratification (warm season). As already explained in Sect. 3.4, this is likely to be the result of both pollution trapping in the presence of near-ground temperature inversions in the cold season (Fig. 1) and enhanced PM emissions from power generation and domestic heating during periods with low temperatures. 


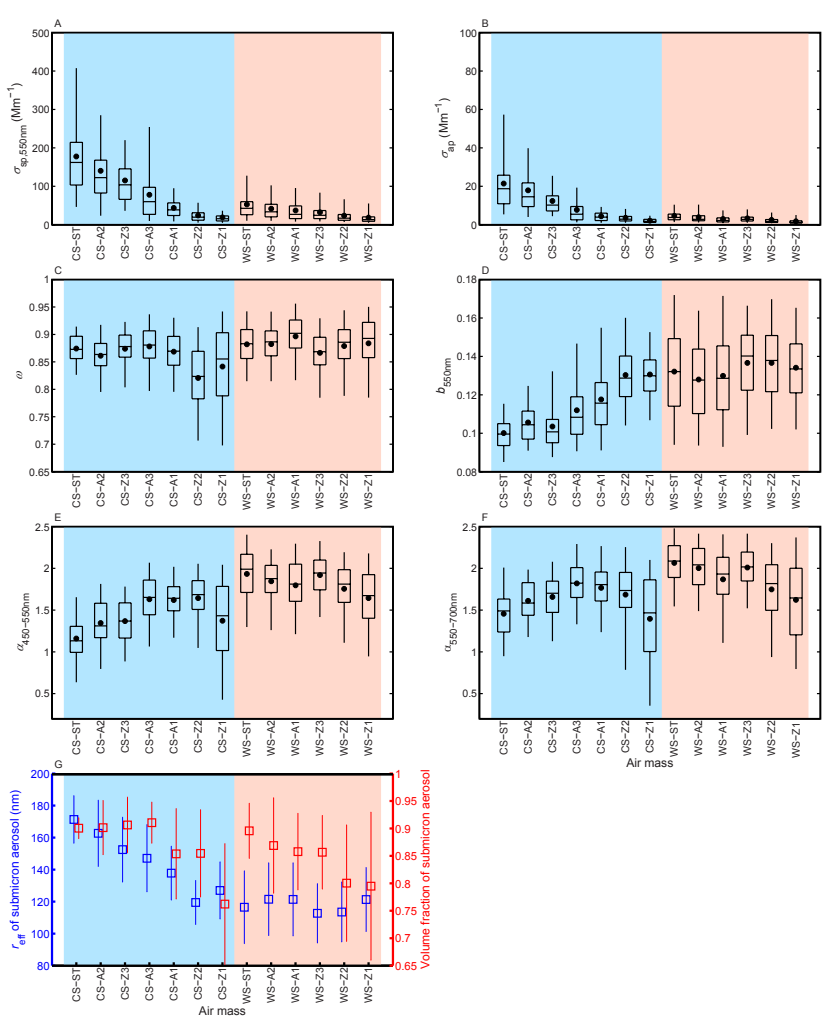

Figure 10. Average aerosol scattering coefficient (A), absorption coefficient (B), single scattering albedo (C), hemispheric backscattering fraction (D), Ångström exponent at 450-550 nm (E) and at 550-700 $\mathrm{nm}(\mathbf{F})$ for the 13 air mass types. For each panel, the boxes and whiskers denote the $5,25,50,75$ and 95 percentiles, while the dots denote the mean values. To have a clear comparison, the average effective radius (blue) and volume fraction (red) of submicron aerosol for the 13 air mass types are also shown in $(\mathbf{G})$, in which whiskers denote the standard deviation.

There remains, however, considerable variation in $\sigma_{\mathrm{sp}}$ and $\sigma_{\mathrm{ap}}$ within each of the two basic air mass groups. As explained below, these variations are obviously a function of the geographic origin of the air mass, which involves rather different residence times of the air mass over continental areas.

The air mass CS-ST, which exhibits the highest aerosol scattering and absorption values, is characterized by low ambient temperatures, a pronounced temperature inversion (Fig. 1), and trajectories remaining over central Europe during four days (Fig. 2). Under these meteorological conditions, the aerosol in the ground layer remains trapped over many days, while anthropogenic sources continue to emit additional particles. We assume that under these conditions, coagulation and aggregation of particles becomes relevant. The observation of the highest effective particle radius in air mass CS-ST (Fig. 10g) might be an indication of this process.

Moving from air mass CS-ST to CS-A2, CS-Z3, CS-A3, CS-A1, CS-Z2 and CS-Z1, the aerosol scattering and absorp- tion values decrease steadily. When looking at the mean trajectories during the corresponding periods (Fig. 2), we note that the residence time of the trajectories over the European continent decrease in a similar fashion. In the air mass types CS-Z2 and CS-Z1, for example, this residence time is around 2 days and lower. Although the residence time over land appears a useful proxy to explain accumulated pollutant concentrations, we are aware of the limitations of this conclusion in that (a) emissions of particles are not equally distributed and (b) particle deposition rates may vary depending on the amount and type of precipitation typically occurring in each of these air mass types.

In the warm season, the atmosphere tends to be neutrally stable at noon (Fig. 1). For aerosol scattering and absorption, we observe the highest values during stagnant conditions (WS-ST). Alike for the cold season, a prolonged stay of an air mass over a continent with anthropogenic pollution sources is a viable explanation for the enhanced concentrations. Next in order are the air masses with predominant anticyclonic flow (WS-A2, WS-A1), followed by such with cyclonic flow (WS-Z3, WS-Z2, WS-Z1). The lowest overall aerosol scattering and absorption values were observed during the advection of sub-Arctic over the North Sea into Germany (WS-Z1). In this air mass, the anthropogenic contributions typical for passage over populated land are visibly the least. When looking at the entire sequence of air masses we note, with one exception (WS-Z3), a decreasing residence time over the continent, very much like in the discussion of the cold season periods above.

For $\omega$, no significant differences can be found between most of the air mass types. However, the $\omega$ in the air masses CS-Z1 and CS-Z2 are evidently lower and show larger variability compared with those in the other air mass types. One possible reason is that these two types of air masses originate from the North Atlantic and are associated with the highest wind speeds. Such clean maritime air has only a short residence time over the continent before reaching Melpitz. The fresh emitted light-absorbing carbonaceous aerosol keeps fresh with less light-scattering component produced in aging processes, and therefore causes a lower $\omega$ in these two air mass types. These air masses also carry a lot of sea salt. However, the sea salt is mostly distributed in coarse mode in which the particles have much lower light scattering efficiency per unit volume (Ma et al., 2014), thus does not contribute much to the aerosol total scattering.

As mentioned in previous sections, the scattering Ångström exponent $\alpha$ varied among different air mass types because of the variation of aerosol number size distribution. In the cold season, due to the favourable condition for pollutant accumulation, both the effective radius and volume fraction of fine-mode aerosol are very sensitive to the originating area and the air mass residence time in the continental atmosphere. $\alpha$ also shows a larger variability. An inverse relationship can be found between $\alpha$ and the fine-mode effective radius in Fig. 10, which coincides with Fig. 7c and e. In the 
warm season, the fine-mode aerosol effective radii are similar for all air mass types and lower than those in the cold season, and thus cause higher level of $\alpha$. With similar finemode effective radius, a positive relationship between $\alpha$ and fine-mode volume fraction can be seen in the warm season in Fig. 10. Moreover, the effect of fine-mode volume fraction

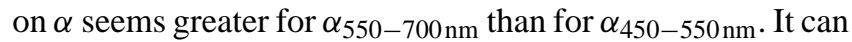
be seen in Fig. $7 \mathrm{~d}$ and $\mathrm{f}$ that although positive relationships can be found between both of the two $\alpha$ and the fine-mode volume fraction, the linear regression for $550-700 \mathrm{~nm}$ shows a higher slope than that for $450-550 \mathrm{~nm}$. The $\alpha_{550-700 \mathrm{~nm}}$ is therefore more sensitive to fine-mode volume fraction than $\alpha_{450-550 \mathrm{~nm}}$. From Figs. 7 and 10 it can be concluded that with the natural variation of aerosol number size distribution in central Europe, both fine-mode effective radius and volume fraction are important in explaining the variation of $\alpha$, but the fine-mode effective radius is more crucial.

From Fig. 10d and g, a pronounced inverse relationship can be found between $b$ and the effective radius of submicron aerosol for all the 13 air mass types, which is in accord with the discussion in Sects. 3.4 and 3.5. The $b$ for most of the air mass types in the warm season are higher than those in the cold season, and show a wider probability distribution. It can be seen in Fig. 8 that the dependence of $b$ on particle size gets higher with the decrease of particle size. Therefore, with lower effective radii in summer, the $b$ shows a higher variability.

\section{Conclusions}

To explore the magnitude and variations of aerosol optical properties in central Europe, we analysed a data set of dry-state aerosol number size distributions, scattering and absorption coefficients collected continuously at a regional background station in East Germany between 2007 and 2010.

To provide a closure for dry-state aerosol optical properties, we compared the measured scattering and hemispheric back scattering $\sigma_{\mathrm{sp}}$ and $\sigma_{\mathrm{bsp}}$ with corresponding values calculated from experimental particle number size distributions and assumed refractive indices, based on a modified Mie model which includes the truncation and non-Lambertian effect of TSI 3563 nephelometer. In the calculation, a twocomponent aerosol model proved to be useful, with the mixing state assumed to be homogeneously internal, external or core-shell internal. In addition, a Monte Carlo simulation was used to evaluate the uncertainties of calculated $\sigma_{\mathrm{sp}}$ and $\sigma_{\text {bsp }}$ induced by the uncertainties of the model inputs. The results show good correlations between the measured and calculated values, with $R^{2}>0.98$ for $\sigma_{\mathrm{sp}}$ and $R^{2}>0.97$ for $\sigma_{\mathrm{bsp}}$, confirming a good quality of the data set. The uncertainty of the calculated $\sigma_{\mathrm{sp}}$ and $\sigma_{\mathrm{bsp}}$ is around $8 \%$ (1 standard deviation). Considering the uncertainties of model inputs, more than 99 and $96 \%$ data records of $\sigma_{\mathrm{sp}}$ and $\sigma_{\mathrm{bsp}}$ satisfy the closure criterion.
The correction factor for truncation and non-Lambertian error of TSI 3563 nephelometer was also calculated from measured particle number size distributions with the modified Mie model. It was found that the calculated correction factors do not match the linear relationship with $\alpha$ given by Anderson and Ogren (1998). Therefore, the parameters derived from the linear fits of calculated correction factors and $\alpha$ were used in the correction of the 4-year nephelometer data.

Comparing with the long-term measurements at the regional background stations in other continents, the average $\sigma_{\mathrm{sp}}$ measured in Melpitz is slightly higher than that measured in the US and is only about $30 \%$ of that measured in North China. The average $\sigma_{\text {ap }}$ measured in Melpitz is about 2.5 times that measured in US and is about $40 \%$ of that measured in North China. The average $\omega$ in Melpitz is obviously lower than those obtained in marine sites (Mace Head, Sable Island and Barrow), and is similar as those measured in regional background sites (Bondville, Hohenpeissenberg, K-Puszta and Shangdianzi) and the Mediterranean site (Finokalia).

All the observed aerosol optical parameters show annual variations. The $\sigma_{\mathrm{sp}}$ and $\sigma_{\mathrm{ap}}$ show much higher values and variations in winter than in summer, mainly attributed to the annual variation of boundary layer height and the local PM emissions. The precipitation scavenging of aerosol may also be a reason for the low values in summer. The single scattering albedo $\omega$ only shows a slight annual variation. Active secondary aerosol formation in summer causes a high level of $\omega$. And the enhanced emission of BC from power generation and domestic heating in winter causes a low level of $\omega$. Both $b$ and $\alpha$ are found to be sensitive to the shape of aerosol number size distribution. The high concentrations of small particles during new particle formation cause a high level of $b$ and $\alpha$ in spring and summer. The mixing state of $\mathrm{BC}$ may also influence the level of $b$ but is less important. All the observed aerosol optical parameters also show some diurnal patterns, with lower contrast compared with their annual variations.

A recently developed air mass classification based on a cluster analysis of daily back trajectories and vertical profiles of pseudo-potential temperature was used to classify the 4-year observations according to daily changes in air mass type. It was found that the atmospheric stability plays an important role for the dry aerosol optical properties measured near the ground. In the cold season, the vertical stratification is overwhelmingly stable, providing a favourable condition for pollutants accumulation. Moreover, the aerosol optical properties turn out to depend sensitively on the air mass residence time over land, the region of origin. In the warm season, in contrast, the atmosphere tends to be well mixed, at least during daytime. This causes the aerosol optical properties to be less sensitive to the origin of the air mass.

In summary, this work has established a statistically robust relationship between the tropospheric particle number size 
distribution and aerosol optical properties observed near the ground. We anticipate that the corresponding results and data will be of use for comparisons with regional transport models, and a further assessment of direct radiative forcing in the central European region. Future investigations will need to look at aerosol optical properties along the vertical dimension of the atmosphere, both on the experimental and computational side.

\section{The Supplement related to this article is available online at doi:10.5194/acp-14-6241-2014-supplement.}

Acknowledgements. Continuous aerosol measurements at Melpitz were supported by the German Federal Environment Ministry (BMU) grants F\&E 370343200 (German title: "Erfassung der Zahl feiner und ultrafeiner Partikel in der Außenluft") and F\&E 371143232 (German title: "Trendanalysen gesundheitsgefährdender Fein- und Ultrafeinstaubfraktionen unter Nutzung der im German Ultrafine Aerosol Network (GUAN) ermittelten Immissionsdaten durch Fortführung und Interpretation der Messreihen"). We also thank Joachim Grüner for his continuous technical support at the Melpitz station.

Edited by: J. Allan

\section{References}

Albrecht, B. A.: Aerosols, cloud microphysics, and fractional cloudiness, Science, 245, 1227-1230, 1989.

Anderson, T. L. and Ogren, J. A.: Determining aerosol radiative properties using the TSI 3563 Integrating Nephelometer, Aerosol Sci. Technol., 29, 57-69, 1998.

Anderson, T. L., Covert, D. S., Marshall, S. F., Laucks, M. L., Charlson, R. J., Waggoner, A. P., Ogren, J. A., Caldow, R., Holm, R. L., Quant, G., Sem, J., Wiedensohler, A., Ahlquist, N. A., and Bates, T. S.: Performance characteristics of a High-sensitivity, three-wavelength total scatter/backscatter nephelometer, J. Atmos. Ocean. Technol., 13, 967-986, 1996.

Asmi, A., Wiedensohler, A., Laj, P., Fjaeraa, A.-M., Sellegri, K., Birmili, W., Weingartner, E., Baltensperger, U., Zdimal, V., Zikova, N., Putaud, J.-P., Marinoni, A., Tunved, P., Hansson, H.C., Fiebig, M., Kivekäs, N., Lihavainen, H., Asmi, E., Ulevicius, V., Aalto, P. P., Swietlicki, E., Kristensson, A., Mihalopoulos, N., Kalivitis, N., Kalapov, I., Kiss, G., de Leeuw, G., Henzing, B., Harrison, R. M., Beddows, D., O'Dowd, C., Jennings, S. G., Flentje, H., Weinhold, K., Meinhardt, F., Ries, L., and Kulmala, M.: Number size distributions and seasonality of submicron particles in Europe 2008-2009, Atmos. Chem. Phys., 11, 5505-5538, doi:10.5194/acp-11-5505-2011, 2011.

Beyrich, F.: Mixing-height estimation in the convective boundary layer using sodar data, Bound. Lay. Meteorol., 74, 1-18, 1995.

Birmili, W., Stratmann, F., and Wiedensohler, A.: Design of a DMA-based size spectrometer for a large particle size range and stable operation, J. Aerosol Sci., 30, 549-533, 1999.
Birmili, W., Wiedensohler, A., Heintzenberg, J., and Lehmann, K.: Atmospheric particle number size distribution in central Europe: Statistical relations to air masses and meteorology, J. Geophys. Res., 106, 32005-32018, 2001.

Birmili, W., Schepanski, K., Ansmann, A., Spindler, G., Tegen, I., Wehner, B., Nowak, A., Reimer, E., Mattis, I., Müller, K., Brüggemann, E., Gnauk, T., Herrmann, H., Wiedensohler, A., Althausen, D., Schladitz, A., Tuch, T., and Löschau, G.: A case of extreme particulate matter concentrations over Central Europe caused by dust emitted over the southern Ukraine, Atmos. Chem. Phys., 8, 997-1016, doi:10.5194/acp-8-997-2008, 2008.

Birmili, W., Weinhold, K., Nordmann, S., Wiedensohler, A., Spindler, G., Müller, K., Herrmann, H., Gnauk, T., Pitz, M., Cyrys, J., Flentje, H., Nickel, C., Kuhlbusch, T. A. J., Löschau, G., Haase, D., Meinhardt, F., Schwerin, A., Ries, L., and Wirtz, K.: Atmospheric aerosol measurements in the German Ultrafine Aerosol Network (GUAN): Part 1 - soot and particle number size distri-butions, Gefahrst. Reinh. Luft, 69, 137-145, 2009.

Birmili, W., Heinke, K., Pitz, M., Matschullat, J., Wiedensohler, A., Cyrys, J., Wichmann, H.-E., and Peters, A.: Particle number size distributions in urban air before and after volatilisation, Atmos. Chem. Phys., 10, 4643-4660, doi:10.5194/acp-10-46432010, 2010.

Bohren, C. F. and Huffman, D. R.: Absorption and Scattering of Light by Small Particles, John Wiley, Hoboken, N. J., 1983.

Buat-Ménard, P. and Duce, R. A.: Precipitation scavenging of aerosol particles over remote marine regions, Nature, 321, 508$510,1986$.

CEN: EN 12341, Air quality - Determination of the PM 10 fraction of suspended particulate matter - Reference method and field test procedure to demonstrate reference equivalence of measurement methods, CEN/TC 264 - Air quality, 1998.

Chandra, S., Satheesh, S. K., and Srinivasan, J.: Can the state of mixing of black carbon aerosols explain the mystery of "excess" atmospheric absorption?, Geophys. Res. Lett., 31, L19109, doi:10.1029/2004GL020662, 2004.

Charlson, R. J., Schwartz, S. E., Hales, J. M., Cess, R. D., Coakley Jr., J. A., Hansen, J. E., and Hofmann, D. J.: Climate forcing by anthropogenic aerosols, Science, 255, 423-430, 1992.

Cheng, Y. F., Berghof, M., Garland, R. M., Wiedensohler, A., Wehner, B., Müller, T., Su, H., Zhang, Y. H., Achtert, P., Nowak, A., Pöschl, U., Zhu, T., Hu, M., and Zeng, L. M.: Influence of soot mixing state on aerosol light absorption and single scattering albedo during air mass aging at a polluted regional site in northeastern China, J. Geophys. Res., 114, D00G10, doi:10.1029/2008JD010883, 2009.

Collaud Coen, M., Weingartner, E., Nyeki, S., Cozic, J., Henning, S., Verheggen, B., Gehrig, R., and Baltensperger, U.: Long-term trend analysis of aerosol variables at the highalpine site Jungfraujoch, J. Geophys. Res., 112, D13213, doi:10.1029/2006JD007995, 2007. 
Collaud Coen, M., Andrews, E., Asmi, A., Baltensperger, U., Bukowiecki, N., Day, D., Fiebig, M., Fjaeraa, A. M., Flentje, H., Hyvärinen, A., Jefferson, A., Jennings, S. G., Kouvarakis, G., Lihavainen, H., Lund Myhre, C., Malm, W. C., Mihapopoulos, N., Molenar, J. V., O’Dowd, C., Ogren, J. A., Schichtel, B. A., Sheridan, P., Virkkula, A., Weingartner, E., Weller, R., and Laj, P.: Aerosol decadal trends - Part 1: In-situ optical measurements at GAW and IMPROVE stations, Atmos. Chem. Phys., 13, 869894, doi:10.5194/acp-13-869-2013, 2013.

Covert, D. S., Heintzenberg, J., and Hansson, H. C.: Electro-optical detection of external mixtures in aerosols, Aerosol Sci. Technol., 12, 446-456, 1990.

DeCarlo, P. F., Slowik, J. G., Worsnop, D. R., Davidovits, P., and Jimenez, J. L.: Particle Morphology and Density Characterization by Combined Mobility and Aerodynamic Diameter Measurements. Part 1: Theory, Aerosol Sci. Technol., 38, 1185-1205, 2004.

Delene, D. J. and Ogren, J. A.: Variability of Aerosol Optical Properties at Four North American Surface Monitoring Sites, J. Atmos. Sci., 59, 1135-1150, 2002.

Dittmann, E., Barth, S., Lang, J., and Müller-Westermeier, G.: Objektive Wetterlagenklassifikation (Objective weather type classification), Ber. Dt. Wetterd. 197, Offenbach a. M., Germany, 1995 (in German).

Draxler, R. R. and Hess, G. D.: Description of the Hysplit_4 Modeling System, NOAA, Technical Memorandum ERL ARL-224, 25 pp., 2004.

Eck, T., Holben, B. N., Reid, J., Dubovik, O., Smirnov, A., O’Neill, N., Slutsker, I., and Kinne, S.: Wavelength dependence of the optical depth of biomass burning, urban, and desert dust aerosols, J. Geophys. Res., 104, 31333-31349, 1999.

Engler, C., Rose, D., Wehner, B., Wiedensohler, A., Brüggemann, E., Gnauk, T., Spindler, G., Tuch, T., and Birmili, W.: Size distributions of non-volatile particle residuals $\left(D_{\mathrm{p}}<800 \mathrm{~nm}\right)$ at a rural site in Germany and relation to air mass origin, Atmos. Chem. Phys., 7, 5785-5802, doi:10.5194/acp-7-5785-2007, 2007.

Genberg, J., Denier van der Gon, H. A. C., Simpson, D., Swietlicki, E., Areskoug, H., Beddows, D., Ceburnis, D., Fiebig, M., Hansson, H. C., Harrison, R. M., Jennings, S. G., Saarikoski, S., Spindler, G., Visschedijk, A. J. H., Wiedensohler, A., Yttri, K. E., and Bergström, R.: Light-absorbing carbon in Europe - measurement and modelling, with a focus on residential wood combustion emissions, Atmos. Chem. Phys., 13, 87198738, doi:10.5194/acp-13-8719-2013, 2013.

Graber, E. R. and Rudich, Y.: Atmospheric HULIS: How humic-like are they? A comprehensive and critical review, Atmos. Chem. Phys., 6, 729-753, doi:10.5194/acp-6-729-2006, 2006.

Hasan, H. and Dzubay, T. G.: Apportioning light extinction coefficients to chemical species in atmospheric aerosol, Atmos. Environ., 17, 1573-1581, 1983.

Heintzenberg, J. and Charlson, R. J.: Design and applications of the integrating nephelometer: a review, J. Atmos. Ocean. Technol., 13, 987-1000, 1996.

Heintzenberg, J., Wiedensohler, A., Tuch, T. M., Covert, D. S., Sheridan, P., Ogren, J. A., Gras, J., Nessler, R., Kleefeld, C., Kalivitis, N., Aaltonen, V., Wilhei, R. T., and Havlicek, M.: Intercomparisons and aerosol calibrations of 12 commercial integrating nephelometers of three manufacturers, J. Atmos. Ocean. Technol., 23, 902-914, 2006.
Heintzenberg, J., Birmili, W., Otto, R., Andreae, M. O., Mayer, J.C., Chi, X., and Panov, A.: Aerosol particle number size distributions and particulate light absorption at the ZOTTO tall tower (Siberia), 2006-2009, Atmos. Chem. Phys., 11, 87038719, doi:10.5194/acp-11-8703-2011, 2011.

Hess, P. and Brezowsky, H.: Katalog der Großwetterlagen Europas (Catalog of the European Large Scale Weather Types). Ber. Dt. Wetterd. in der US-Zone 33, Bad Kissingen, Germany, 1952 (in German).

Hyvärinen, A. P., Lihavainen, H., Komppula, M., Sharma, V. P., Kerminen, V. M., Panwar, T. S., and Viisanen, Y.: Continuous measurements of optical properties of atmospheric aerosols in Mukteshwar, northern India, J. Geophys. Res., 114, D08207, doi:10.1029/2008JD011489, 2009.

IPCC 2013: Myhre, G., Shindell, D., Bréon, F.-M., Collins, W., Fuglestvedt, J., Huang, J., Koch, D., Lamarque, J.-F., Lee, D., Mendoza, B., Nakajima, T., Robock, A., Stephens, G., Takemura, T., and Zhang, H.: Anthropogenic and Natural Radiative Forcing, in: Climate Change 2013: The Physical Science Basis. Contribution of Working Group I to the Fifth Assessment Report of the Intergovernmental Panel on Climate Change, edited by: Stocker, T. F., Qin, D., Plattner, G.-K., Tignor, M., Allen, S. K., Boschung, J., Nauels, A., Xia, Y., Bex, V., and Midgley, P. M., Cambridge University Press, Cambridge, United Kingdom and New York, NY, USA, 2013.

Jacobson, M. Z.: Strong radiative heating due to the mixing state of black carbon in atmospheric aerosols, Nature, 409, 695-697, 2001.

Jaffrezo, J. L. and Colin, J. L.: Rain-aerosol coupling in urban area: scavenging ratio measurement and identification of some transfer processes, Atmos. Environ., 22, 929-935, 1988.

Jennings, S. G., Kleefeld, C., O’Dowd, C. D., Junker, C., Spain, T. G., O'Brien, P., Roddy, A. F., and O'Connor, T. C.: Mace Head Atmospheric Research Station-characterization of aerosol radiative parameters, Boreal Environ. Res., 8, 303-314, 2003.

Kaaden, N., Massling, A., Schladitz, A., Müller, T., Kandler, K., Schütz, L., Weinzierl, B., Petzold, A., Tesche, M., Leinert, S., Deutscher, C., Ebert, M., Weinbruch, S., and Wiedensohler A.: State of mixing, shape factor, number size distribution, and hygroscopic growth of the Saharan anthropogenic and mineral dust aerosol at Tinfou, Morocco, Tellus B, 61, 51-63, 2009.

Kaminski, U.: Aktuelle Aerosoltrends an der GAW Globalstation Hohenpeißenberg und ihre Relevanz für Luftreinhaltung und Klima, Umweltwissenschaften und Schadstoff-Forschung, 18, 88-94, 2006.

Katrinak, K. A., Rez, P., and Buseck, P. R.: Structural variations in individual carbonaceous particles from an urban aerosol, Environ. Sci. Technol., 26, 1967-1976, 1992.

Katrinak, K. A., Rez, P., Perkes, P. R., and Buseck, P. R.: Fractal geometry of carbonaceous aggregates from an urban aerosol, Environ. Sci. Technol., 27, 539-547, 1993.

Leskinen, A., Arola, A., Komppula, M., Portin, H., Tiitta, P., Miettinen, P., Romakkaniemi, S., Laaksonen, A., and Lehtinen, K. E. J.: Seasonal cycle and source analyses of aerosol optical properties in a semi-urban environment at Puijo station in Eastern Finland, Atmos. Chem. Phys., 12, 5647-5659, doi:10.5194/acp-12-56472012, 2012. 
Liu, P., Zhao, C., Zhang, Q., Deng, Z., Huang, M., Ma, X., and Tie, X.: Aircraft study of aerosol vertical distributions over Beijing and their optical properties, Tellus B, 61, 756-767, 2009.

Ma, N., Zhao, C. S., Nowak, A., Müller, T., Pfeifer, S., Cheng, Y. F., Deng, Z.Z., Liu, P. F., Xu, W. Y., Ran, L., Yan, P., Göbel, T., Hallbauer, E., Mildenberger, K., Henning, S., Yu, J., Chen, L. L., Zhou, X. J., Stratmann, F., and Wiedensohler, A.: Aerosol optical properties in the North China Plain during HaChi campaign: an in-situ optical closure study, Atmos. Chem. Phys., 11, 59595973, doi:10.5194/acp-11-5959-2011, 2011.

Ma, N., Zhao, C. S., Müller, T., Cheng, Y. F., Liu, P. F., Deng, Z. Z., Xu, W. Y., Ran, L., Nekat, B., van Pinxteren, D., Gnauk, T., Müller, K., Herrmann, H., Yan, P., Zhou, X. J., and Wiedensohler, A.: A new method to determine the mixing state of light absorbing carbonaceous using the measured aerosol optical properties and number size distributions, Atmos. Chem. Phys., 12, 23812397, doi:10.5194/acp-12-2381-2012, 2012.

Ma, N., Zhao, C. S., Chen, J., Xu, W. Y., Yan, P., and Zhou, X. J.: A novel method for distinguishing fog and haze based on PM2.5, visibility, and relative humidity, Sci. China Earth Sciences, doi:10.1007/s11430-014-4885-5, in press, 2014.

McMurry, P. H., Wang, X., Park, K., and Ehara, K.: The relationship between mass and mobility for atmospheric particles: A new technique for measuring particle density, Aerosol Sci. Tech., 36, 227-238, 2002.

Mie, G.: Beiträge zur optic trüber Medien speziell kolloidaler Metallösungen, Ann. Phys., 25, 377-445, 1908.

Molnár, A. and Mészáros, E.: On the relation between the size and chemical composition of aerosol particles and their optical properties, Atmos. Environ., 35, 5053-5058, 2001.

Müller, T., Wiedensohler, A., Nowak, A., Laborde, M., Covert, D. S., Sheridan, P. J., Marinoni, A., Imre, K., Henzing, B., Roger, J. C., Martins dos Santos, S., Wilhelm, R., Wang, Y. Q., and de Leeuw, G.: Angular illumination and truncation of three different integrating nephelometers: implications for empirical, size-based corrections, Aerosol Sci. Tech., 43, 581-586, 2009.

Müller, T., Henzing, J. S., de Leeuw, G., Wiedensohler, A., Alastuey, A., Angelov, H., Bizjak, M., Collaud Coen, M., Engström, J. E., Gruening, C., Hillamo, R., Hoffer, A., Imre, K., Ivanow, P., Jennings, G., Sun, J. Y., Kalivitis, N., Karlsson, H., Komppula, M., Laj, P., Li, S.-M., Lunder, C., Marinoni, A., Martins dos Santos, S., Moerman, M., Nowak, A., Ogren, J. A., Petzold, A., Pichon, J. M., Rodriquez, S., Sharma, S., Sheridan, P. J., Teinilä, K., Tuch, T., Viana, M., Virkkula, A., Weingartner, E., Wilhelm, R., and Wang, Y. Q.: Characterization and intercomparison of aerosol absorption photometers: result of two intercomparison workshops, Atmos. Meas. Tech., 4, 245-268, doi:10.5194/amt-4-245-2011, 2011.

Ouimette, J. R. and Flagan, R. C.: The extinction coefficient of multicomponent aerosols, Atmos. Environ., 16, 2405-2419, 1982.

Petzold, A. and Schönlinner, M.: Multi-angle absorption photometry a new method for the measurement of aerosol light absorption and atmospheric black carbon, J. Aerosol Sci., 35, 421-441, 2004.
Pfeifer, S., Birmili, W., Schladitz, A., Müller, T., Nowak, A., and Wiedensohler, A.: A fast and easy-to-implement inversion algorithm for mobility particle size spectrometers considering particle number size distribution information outside of the detection range, Atmos. Meas. Tech., 7, 95-105, doi:10.5194/amt-795-2014, 2014.

Philipp, A., Bartholy, J., Beck, C., Erpicum, M., Esteban, P., Fettweis, X., Huth, R., James, P., Jourdain, S., Kreienkamp, F., Krennert, T., Lykoudis, S., Michalides, S. C., PiankoKluczynska, K., Post, P., Álvarez, D. R., Schiemann, R., Spekat, A., and Tymvios, F. S.: Cost733cat-A database of weather and circulation type classifications, Phys. Chem. Earth, Parts A/B/C, 35, 360-373, 2010.

Poulain, L., Spindler, G., Birmili, W., Plass-Dülmer, C., Wiedensohler, A., and Herrmann, H.: Seasonal and diurnal variations of particulate nitrate and organic matter at the IfT research station Melpitz, Atmos. Chem. Phys., 11, 12579-12599, doi:10.5194/acp-11-12579-2011, 2011 a.

Poulain, L., Iinuma, Y., Müller, K., Birmili, W., Weinhold, K., Brüggemann, E., Gnauk, T., Hausmann, A., Löschau, G., Wiedensohler, A., and Herrmann, H.: Diurnal variations of ambient particulate wood burning emissions and their contribution to the concentration of Polycyclic Aromatic Hydrocarbons (PAHs) in Seiffen, Germany, Atmos. Chem. Phys., 11, 12697-12713, doi:10.5194/acp-11-12697-2011, 2011 b.

Quinn, P. K., Anderson, T. L., Bates, T. S., Dlugi, R., Heintzenberg, J., Hoyningen-Huene, W. v., Kulmala, M., Russell, P. B., and Swietlicki, E.: Closure in tropospheric aerosol-climate research: A review and future needs for addressing aerosol direct shortwave radiative forcing, Phys. Atmos., 69, 547-577, 1996.

Rizzo, L. V., Artaxo, P., Müller, T., Wiedensohler, A., Paixão, M., Cirino, G. G., Arana, A., Swietlicki, E., Roldin, P., Fors, E. O., Wiedemann, K. T., Leal, L. S. M., and Kulmala, M.: Long term measurements of aerosol optical properties at a primary forest site in Amazonia, Atmos. Chem. Phys., 13, 2391-2413, doi:10.5194/acp-13-2391-2013, 2013.

Rosenfeld, D.: TRMM observed first direct evidence of smoke from forest fires inhibiting rainfall, Geophys. Res. Lett., 26, 31053180, 1999.

Rosenfeld, D.: Suppression of rain and snow by urban and industrial air pollution, Science, 287, 1793-1796, 2000.

Schuster, G. L., Dubovik, O., and Holben, B. N.: Ångström exponent and bimodal aerosol size distributions, J. Geophys. Res., 111, D07207, doi:10.1029/2005JD006328, 2006.

Seinfeld, J. and Pandis, S.: Atmospheric chemistry and physics: from air pollution to climate change, Wiley, Inc., New York, 1998.

Sloane, C. S.: Optical properties of aerosols - Comparison of measurements with model calculations, Atmos. Environ., 17, 409416, 1983.

Sloane, C. S.: Optical properties of aerosols of mixed composition, Atmos. Environ., 18, 871-878, 1984.

Sloane, C. S. and Wolff, G. T.: Prediction of ambient light scattering using a physical model responsive to relative humidity: Validation with measurements from Detroit, Atmos. Environ., 19, 669-680, 1985. 
Sloane, C. S., Watson, J., Chow, J., Pritchett, L., and Richards, L. W.: Size-segregated fine particle measurements by chemical species and their impact on visibility impairment in Denver, Atmos. Environ., Part A, 25, 1013-1024, 1991.

Takemura, T., Nakajima, T., Dubovik, O., Holben, B. N., and Kinne, S.: Single scattering albedo and radiadive forcing of various aerosol species with a global three dimensional model, J. Climate, 15, 333-352, 2002.

Tang, I. N. and Munkelwitz, H. R.: Water activities, densities and refractive indices of aqueous sulfates and sodium nitrate droplets of atmospheric importance, J. Geophys. Res., 99, 18801-18808, 1994.

Tanré, D., Kaufman, Y. J., Herman, M., and Mattoo, S.: Remote sensing of aerosol properties over oceans using the MODIS/EOS spectral radiances, J. Geophys. Res., 102, 16971-16988, 1997.

Tuch, T. M., Haudek, A., Müller, T., Nowak, A., Wex, H., and Wiedensohler, A.: Design and performance of an automatic regenerating adsorption aerosol dryer for continuous operation at monitoring sites, Atmos. Meas. Tech., 2, 417-422, doi:10.5194/amt-2-417-2009, 2009.

Twomey, S.: Pollution and the planetary albedo, Atmos. Environ., 8, 1251-1256, 1974.

van Donkelaar, A., Martin, R. V., Brauer, M., Kahn, R., Levy, R., Verduzco, C., and Villeneuve, P. J.: Global estimates of ambient fine particulate matter concentrations from satellite-based aerosol optical depth: Development and application, Environ. Health Perspect., 118, 847-855, 2010.

Vrekoussis, M., Liakakou, E., Kocak, M., Kubilay, N., Oikonomou, K., Sciare, J., and Mihalopoulos, N.: Seasonal variability of optical properties of aerosols in the Eastern Mediterranean, Atmos. Environ., 39, 7083-7094, 2005.

Westphal, D. and Toon, O.: Simulations of microphysical, radiative, and dynamical processes in a continental-scale forest fire smoke plume, J. Geophys. Res., 96, 22379-22400, 1991.

Wex, H., Neusüß C., Wendisch M., Stratmann F., Koziar C., Keil A., Wiedensohler A., and Ebert M.: Particle scattering, backscattering, and absorption coefficients: An in situ closure and sensitivity study, J. Geophys. Res., 107, 8122, doi:10.1029/2000JD000234, 2002.
Wiedensohler, A., Orsini, D., Covert, D. S., Coffmann, D., Cantrell, W., Havlicek, M., Brechtel, F. J., Russell, L. M., Weber, R. J., Gras, J., Hudson, J. G., and Litchy, M.: Intercomparsion study of the size-dependent counting efficiency of 26 condensation particle counters, Aerosol Sci. Technol., 27, 224-242, 1997.

Wiedensohler, A., Birmili, W., Nowak, A., Sonntag, A., Weinhold, K., Merkel, M., Wehner, B., Tuch, T., Pfeifer, S., Fiebig, M. Fjäraa, A. M., Asmi, E., Sellegri, K., Depuy, R., Venzac, H., Villani, P., Laj, P., Aalto, P., Ogren, J. A., Swietlicki, E., Williams, P., Roldin, P., Quincey, P., Hüglin, C., Fierz-Schmidhauser, R., Gysel, M., Weingartner, E., Riccobono, F., Santos, S., Grüning, C., Faloon, K., Beddows, D., Harrison, R., Monahan, C., Jennings, S. G., O’Dowd, C. D., Marinoni, A., Horn, H.-G., Keck, L., Jiang, J., Scheckman, J., McMurry, P. H., Deng, Z., Zhao, C. S., Moerman, M., Henzing, B., de Leeuw, G., Löschau, G., and Bastian, S.: Mobility particle size spectrometers: harmonization of technical standards and data structure to facilitate high quality long-term observations of atmospheric particle number size distributions, Atmos. Meas. Tech., 5, 657-685, doi:10.5194/amt5-657-2012, 2012.

Winkler, P.: The growth of atmospheric aerosol particles as a function of the relative humidity - II An improved concept of mixed nuclei, J. Aerosol Sci., 4, 373-387, 1973.

Yan, P., Tang, J., Huang, J., Mao, J. T., Zhou, X. J., Liu, Q., Wang, Z. F., and Zhou, H. G.: The measurement of aerosol optical properties at a rural site in Northern China, Atmos. Chem. Phys., 8, 2229-2242, doi:10.5194/acp-8-2229-2008, 2008.

Zieger, P., Fierz-Schmidhauser, R., Poulain, L., Müller, T., Birmili, W., Spindler, G., Wiedensohler, A., Baltensperger, U., and Weingartner, E.: Influence of water uptake on the aerosol particle light scattering coefficients of the Central European aerosol, Tellus B, 66, 22716, doi:10.3402/tellusb.v66.22716, 2014. 